\title{
Background on the control of the cattle tick R. (B.) microplus and the use of coumarin substances as an alternative
}

\begin{abstract}
Rhicephalus (Boophilus) microplus (R. (B.) microplus) is a hematophagous ectoparasite of Indo-Asian origin that is found in tropical and subtropical regions, which has expanded its geographical distribution as a result of climate change, migrating to northern latitudes and higher altitudes. This species creates estimated economic losses between $\$ 13.9$ and 18.7 million dollars per year, generating direct and indirect effects on livestock such as low productivity and production rates, decreased reproduction, and even death through the transmission of diseases associated with this species, including diseases known as TBD (tick borne diseases), which are a public health problem in countries with high rates of occurrence, such as the United States, the United Kingdom, Russia, France, Australia and Brazil.

The chemical control of cattle ticks began in 1895 with the use of arsenic baths that reduced infestation of this species in herds in Australia. Today, many formulations and techniques have been developed to control of this species; however, malpractice, underdosing and/ or overuse of these substances have allowed this species to develop different types of resistance, which have documented worldwide. Countries with a high number of resistance reports include Mexico, Brazil and Australia.

These factors serve as a starting point for research that seeks to provide economically and environmentally viable alternatives for the control of cattle ticks, which make use of different types of plant extracts obtained from many species. As a result, high control rates at different stages of this species using various compounds with a less harmful effect on the environment have been achieved, such as with coumarins, which are obtained from chemical reactions using methodologies designed with the concept of green chemistry. This paper sought to provide an overview and approximation of the traditional control of $R$. (B.) microplus and control alternatives that use coumarin compounds.
\end{abstract}

Keywords: coumarins, control, resistance, acaricides, vector, environmentally viable alternatives
Volume 8 Issue 4 - 2020

\section{Carlos-Eduardo Rodríguez-Molano,' Sergio Ulloa Torres, ${ }^{2}$ Laura-Estefanía Niño Monrroy ${ }^{2}$ 'Escuela de Medicina Veterinaria y Zootecnia, Universidad Pedagógica y Tecnológica de Colombia, Lead Researcher, Grupo de Investigación en Bioquímica y Nutrición Animal GIBNA, Colombia \\ 2Universidad Pedagógica y Tecnológica de Colombia, Researcher, Grupo de Investigación en Bioquímica y Nutrición Animal GIBNA, Colombia}

\author{
Correspondence: Carlos-Eduardo Rodríguez, Escuela de \\ Medicina Veterinaria y Zootecnia, Universidad Pedagógica \\ y Tecnológica de Colombia, Lead Researcher, Grupo de \\ Investigación en Bioquímica y Nutrición Animal GIBNA, Tunja, \\ Boyaca, Colombia, Tel +573044150615, \\ Email carlos.rodrguez@uptc.edu.co
}

Received: July 14, 2020 | Published: July 30, 2020

\section{Introduction}

The cattle tick $R$. (B.) microplus is a hematophage ectoparasite of great importance worldwide because it causes considerable economic losses to the meat and dairy industry, ${ }^{1}$ losses that they are directly associated with a lower weight gain and milk production. ${ }^{2}$ In addition, it is a vector of zoonotic diseases, including anaplasmosis, babesiosis, ehrlichiosis and Lyme disease. ${ }^{3,4}$

Given the importance of this pest, chemically synthesized acaricides have traditionally been used to reduce infestations in cattle, generating a series of problems associated with environmental pollution, loss of food quality through the presence of agrochemicals in meat and milk, and significant economic losses worldwide. ${ }^{5,6}$ Different authors have reported that $R$. (B.) microplus has generated resistance to acaricides as a result of continuous and improper use, ${ }^{7}$ generating interest in investigating plant extracts with ixodicidal properties as a sustainable alternative with low or no toxicity to mammals, rapid degradation in the environment and greater impediment for the development of resistance that is economically viable. ${ }^{8,9}$ Studies have used different species, showing high levels of developmental inhibitory action for eggs and adult control, suggesting that they are a viable alternative for the control of this tick. ${ }^{9-11}$
Secondary metabolites such as isoflavones, flavones, flavonols, neoflavones and coumarins have been isolated from plant extracts. ${ }^{12}$

Coumarins have been studied since 1860 , revealing wide range of antiviral, antiparasitic, antifungal, and insecticidal activities, among others. ${ }^{13}$ Because of their importance in different types of industries, there is a large amount of research on obtaining them, isolating them naturally or through chemical synthesis. As a result, there are approximately 1300 coumarins isolated from different plant families. ${ }^{14-16}$ The various procurement processes have generated variations in structure and possible use, so the insecticidal activity has been studied, demonstrating great potential for the control of different species of mosquitoes, ticks and other pests that transmit diseases in humans, animals and plant species. ${ }^{17}$

\section{Materials and methods}

This paper was developed with a review of research literature and publications of scientific importance that have impacted knowledge on the cattle tick $R$. (B.) microplus, mainly through exploration of types of control with an emphasis on plant extracts containing coumarins. The cited articles were considered for this review, but not all studies on which the research was based were included. 
The objective was to provide an overview and approximation of the traditional control of $R$. (B.) microplus and control alternatives that use coumarin compounds, taking into account the literature and discussions on the use of plant extracts for controlling this ectoparasite.

\section{Rhipicephalus (Boophilus) microplus}

The cattle tick $R$. (B.) microplus is a species of Indo-Asian origin ${ }^{18}$ that is widely distributed in tropical and subtropical regions between $32^{\circ} \mathrm{N}$ and $35^{\circ} \mathrm{S}$ latitude, in areas with an average annual rainfall of 750 to $1000 \mathrm{~mm}$, a temperature range between $12^{\circ} \mathrm{C}$ and $24^{\circ} \mathrm{C}$ and altitudes from 250 to 1600 meters above sea level; 919 however, as a result of climate change, $R$. (B.) microplus has expanded its geographical distribution to northern latitudes and higher altitudes, ${ }^{20}$ as reported by Pulido-Herrera et al., ${ }^{18}$ who observed the presence of $R$. (B.) microplus at altitudes above 2,750 m.a.s.l., with temperatures below $12^{\circ} \mathrm{C}$ and $500 \mathrm{~mm}$ of rainfall, in the Cundiboyacense highlands of Colombia.

This ectoparasite lives on the surface of a host, ${ }^{21}$ feeding on the blood without mortality but can transmit different pathogens. ${ }^{22}$ Its life cycle is divided into two phases: the non-parasitic phase comprised of pre-oviposition, oviposition, pre-hatching and hatching, and the parasitic phase with feeding, molting and mating. The duration of the cycle is influenced by environmental factors such as climate and vegetation ${ }^{23}$ however, the duration of the cycle under controlled conditions $\left(28 \pm 3^{\circ} \mathrm{C}\right.$ and $\left.80 \pm 5 \% \mathrm{RH}\right)$ has an approximate duration of 49 to 81 days. ${ }^{24}$

\section{Transmitted diseases}

Ticks are the second most important vector worldwide, after mosquitoes, and are carriers of causative or infectious agents of diseases, called tick borne diseases (TBD). ${ }^{5}$ TBD incidence has increased through the spread of ticks linked to climatic changes. Rodríguez et al., ${ }^{25}$ made a conglomerate of global reports of diseases related to tick bites with a geographical distribution that included countries such as the US, UK, Russia, France, Argentina, Brazil, Spain, and Israel, among others. NCEZID ${ }^{26}$ in turn, reported on the increase of cases of Lyme disease that has occurred in the US from 2016 to 2017, from 26,203 to 29,513 . In addition, it has been estimated that effects from ticks are seen in $80 \%$ of the cattle population worldwide. ${ }^{27}$

These diseases can be transmitted from ticks to vertebrates, ${ }^{4}$ the more important being the Jiangmen tick virus (JMTV), Lihan tick virus (LITV) and Wuhan tick virus (WTV-2), among other viruses, ${ }^{28-30}$ bacteria, such as rickettsia (Rickettsia spp), causative agents of spotted rocky mountain fever, and spotted Mediterranean fever, ${ }^{31,32}$ and Anaplasma marginale, which is the causative agent of bovine anaplasmosis and human granulocytic anaplasmosis. ${ }^{33,34}$ The bacteria transmitted by ticks include spirochetes (Borrelia spp), which cause Lyme disease, recurrent fever and rash disease, associated with the southern tick. ${ }^{35,36}$

\section{Economic importance}

The cattle tick has a great economic impact on the livestock industry through blood feeding and the transmission of pathogens. According to Meng \& Sluder, ${ }^{23}$ a reliable number of economic losses worldwide caused by cattle ticks was indicated by Brown \& Askenase, ${ }^{37}$ who reported economic losses estimated at US $\$ 8$ billion caused by ticks in 1984; however, Betancur Hurtado \& Giraldo-Ríos, ${ }^{38}$ observed US $\$ 18.7$ million in annual losses caused by $R$. (B.) microplus worldwide. Several authors have presented varying values depending on the country (Table 1). Finally, Lew-Tabor \& Rodríguez Valle, ${ }^{39}$ stated that the total estimated economic loss per animal per year (production plus control cost) can reach US \$22-30 thousand per year.

Table I Report of economic losses caused by R. (B.) microplus, according to different sources

\begin{tabular}{|c|c|c|}
\hline Country & Losses in \$ USD & Author/Year \\
\hline Brazil & $\$ 3,240,000,000$ & Grisi et al..40 \\
\hline USA & $\$ 3,000,000,000$ & Graham \& Hourrigan ${ }^{41}$ \\
\hline Mexico & $\$ 573,610,000$ & Rodríguez-Vivas et al.,"2 \\
\hline India & $\$ 498,700,000$ & Senbill et al.., ${ }^{24}$ \\
\hline Australia & $\$ 62,000,000$ & Manjunathachar et al.,27 \\
\hline Colombia & $\$ 25,300,000$ & Puerta et al., ${ }^{43}$ \\
\hline Puerto Rico & $\$ 6,700,000$ & Senbill et al., ${ }^{24}$ \\
\hline Zambia & $\$ 5,000,000$ & Senbill et al.., \\
\hline
\end{tabular}

\section{Chemical control of $R_{\text {. }}\left(B_{\text {. }}\right)$ microplus}

Historically, tick infestations in cattle have been controlled using chemical acaricides with various active ingredients and application methods, such as immersion or sprinkling. ${ }^{23}$ This type of control began at the end of the 19th century with the use of arsenic and then advanced to formulations produced from active ingredients such as organochlorines, organophosphates, carbamates, amidines, pyrethroids, phenylpyrazoles, cyclic lactones, and growth regulators of insects and isoxazolines (Table 2). . $^{8,23,44-46}$

Table 2 Introduction, mode and point of action of active ingredients used as acaricides worldwide

Active Ingredient/

$\begin{array}{lll}\text { year of } & \text { Formulations } & \text { Action Mechanism }\end{array}$

introduction $^{23}$

Arsenic 1895

Arsenic Trioxide, Potassium Arsenite, Dihydro-I, 3, 2, -dithiarsenol-2mercaptoacetic acid

Organophosphates 1955
Ethion, Chlorpyrifos, Chlorphenvinphs And Coumaphos
Inhibit pyruvate dehydrogenase, competing with phosphate, decoupling oxidative phosphorylation, causing reduced energy-linked nicotinamide dinucleotide, mitochondrial respiration and the synthesis of adenosine triphosphate, leading to death. ${ }^{47}$

Act at the synapse of nerve junctions and inhibit the activity of acetylcholinesterase irreversibly, producing continuous nerve discharges that cause paralysis and death. ${ }^{48}$
IRAC Grouping according to the action mechanism and point

Pyruvate dehydrogenase (NADP +)/respiratory system inhibitors

Acetylcholinesterase/nervous system inhibitors 
Table Continued...

$\begin{array}{llll}\begin{array}{l}\text { Active Ingredientl } \\ \text { year of }\end{array} & \text { Formulations } & \text { Action Mechanism } & \text { IRAC Grouping according } \\ \text { introduction } & & \text { to the action mechanism } & \text { and point }\end{array}$

Carbamates $1956 \quad$ Carbaryl,Aldicarb, Carbofuran

Oxamyl, Propoxur

\begin{tabular}{|c|c|}
\hline \multirow{4}{*}{ Organochlorines 1939} & Chlorinated Ethane Derivatives: DDT, \\
\hline & $\begin{array}{l}\text { DDE (Dichloro-diphenyldichloro-ethane) } \\
\text { and DDD (Dicofol, Methoxychloro) }\end{array}$ \\
\hline & $\begin{array}{l}\text { Cyclodiene, Chlordane, Aldrine, } \\
\text { Dieldrin, Hepatochlor, Endrin, Toxaphene. }\end{array}$ \\
\hline & $\begin{array}{l}\text { Hexachlorocyclohexanes }(\mathrm{HCH}) \text { : } \\
\text { Benzene Hexachloride }(\mathrm{BHC}) \\
\text { that includes } \gamma \text {-isomer, lindane }\end{array}$ \\
\hline
\end{tabular}

Pyrethroids $1978 \quad$ Cypermethrin, Deltamethrin,

Cyhalotrin and Flumethrin

Phenylpyrazoles $1995 \quad$ Fipronil, Pyriprole

Isoxazolines 2013

Afoxolaner, Fluralaner, Sarolaner, Lotilaner, CPD I

Binding to the picrotoxin site in the gamma aminobutyric acid chloride $(\mathrm{Cl}-)$ ionophores complex (GABA), which inhibits the flow of $C$ into the nerve and causes hyperexcitation and death $^{49}$

GABA receptor (chlorine channel)/nervous system antagonists
Amidines 1975

Cyclic Lactones 198I

1994
Amitraz, Clordimeform, Clenpirin, Chloromethurgon

Avermectin: Doramectin, Selamectin, Abamectin, Ivermectin and Eprinomectin.

Milbemycins: Moxidectin, Milbemycin Oxima

Spinosyns: Spinosad

Chitin synthesis inhibitors (Benzoylphenylureas),

Chitin inhibitors

(Triazine/Pyrimidine derivatives)
Block the movement of sodium ions along the axon of the nerve fiber. Stimulate repetitive nerve discharges that lead to paralysis and death. ${ }^{50}$

Binds to the allosteric sites of the GABAA and $\mathrm{GluCl}$ channels,

acting as an antagonist (non-competitive inhibition), which prevents the opening of the $\mathrm{Cl}$ channels normally promoted by $\mathrm{GABA}^{49}$

Non-competitive GABA receptor antagonists that bind to $\mathrm{Cl}$-channels in nerve and muscle cells blocking the transmission of neuronal channels, paralysis and death. ${ }^{49}$

Competing with octopamine for its receptor site, guanosine diphosphate is replaced by guanosine triphosphate, which induces the production of cyclic adenosine monophosphate that leads to inhibition of binding and, finally, to blood feeding, with the final death. ${ }^{47}$

Bind to GABA and glutamate-regulated chloride channels ( $\mathrm{GluCl}$ ), which opens chloride channels in the nerves, resulting in disruption of activity and loss of function in these cells that lead to paralysis and Death. ${ }^{51}$
Octopamine/nervous system receptor agonist

Nicotinic acetylcholine receptor agonists/antagonists

Juvenile Hormone Analogs

Structural resemblance to the molting hormone, 20-hydroxyecdsyone, thus interrupting the molting, metamorphosis and development of the female reproductive system. Surviving ticks are unable to produce a progeny. ${ }^{45}$
Chitin biosynthesis inhibitorsAcetyl CoA carboxylase inhibitors/hormone imbalance

\section{Resistance to chemical control}

The intensive use of chemical acaricides has resulted in populations of ticks that exhibit resistance, understood as a characteristic or set of specific inherited traits resulting from the contact of said population with an acaricide, which results in significant increases of the percentage of the population that survives exposure to a certain concentration. ${ }^{42}$ In 2019, the Insecticide Resistance Action
Committee (IRAC) ${ }^{47}$ defined resistance as an inheritable change in the sensitivity of a population of a pest that is reflected in repeated failures of a product to reach the expected levels of control when used in accordance with the label recommendations for that pest.

The evaluation of the effectiveness of these products has shown the time that has elapsed from introduction until the development of resistances. Meng \& Sluder ${ }^{23}$ developed a timeline (Figure 1) that 
shows the years that have elapsed since introduction of an acaricide until the first report of resistance. The first evidence of a population of resistant ticks was presented by Mackerras, ${ }^{53}$ who, based on evidence received 10 years earlier from the Ayr district in Queensland
(Australia), reported a decrease in the number of dead ticks after arsenic immersion baths, a situation that, according to the same author, was seen in South Africa and Argentina.

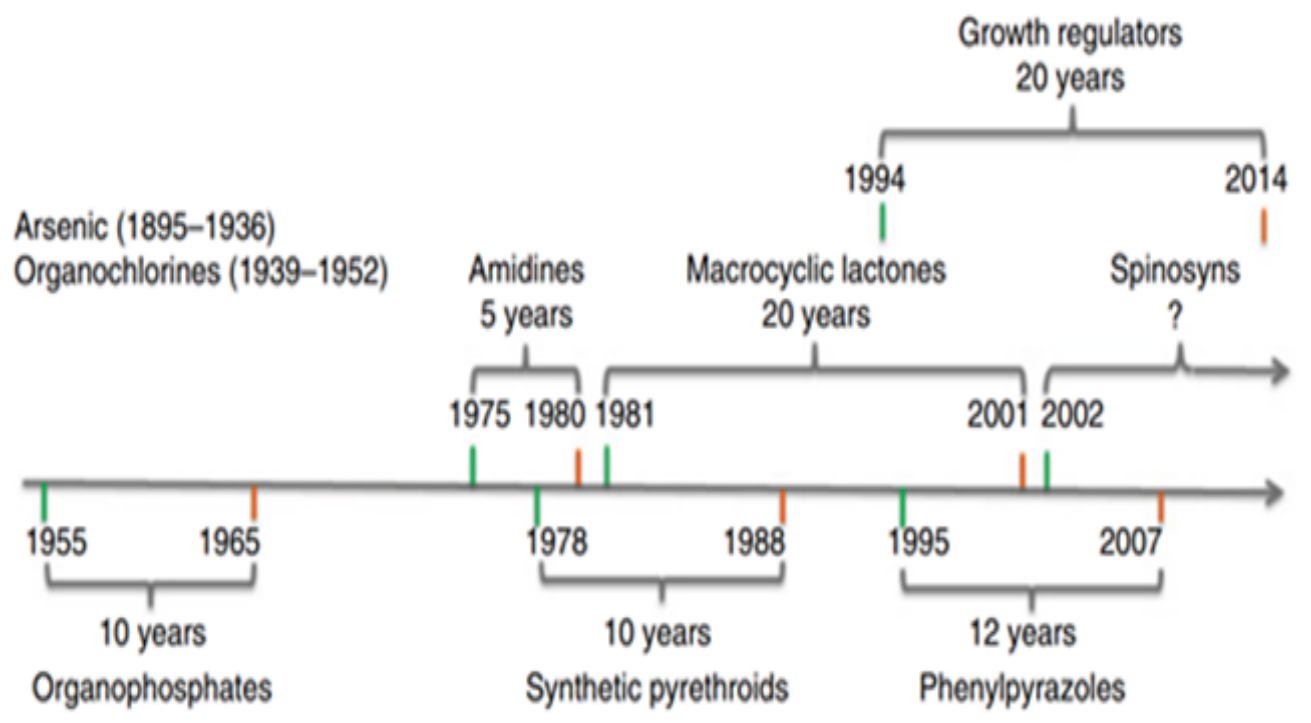

Figure I Chronological order of the introduction of acaricides used for tick control (green marker date) and the first resistance report according to the respective group (red marker date). ${ }^{23}$

The review by Adenubi et al., ${ }^{12}$ in 2018 , which has been modified by the authors, including reports from 2019 (Table 3), showed that there are 204 studies that show resistance to different active ingredients and formulations in $R$. (B.) microplus, with 134 of the studies from the Americas, where Mexico has the highest number of resistance reports, 42 in total, followed by Brazil (27) Australia (23), India (18) and Colombia (17). On the other hand, the active ingredient with the highest number of reports is cypermethrin.

Table 3 Historical reports of resistance generated by R. (B.) microplus worldwide

\begin{tabular}{|c|c|c|c|c|}
\hline Continent & Country & Reference & Year & Acaricide or active ingredient \\
\hline Africa & Benin & Adehan et al., ${ }^{54}$ & 2016 & Alpha-cypermethrin \\
\hline Africa & Benin & Adehan et al., ${ }^{54}$ & 2016 & deltamethrin \\
\hline Africa & Benin & Adehan et al., ${ }^{54}$ & 2016 & Amitraz \\
\hline Africa & Egipto & Aboelhadid et al., ${ }^{50}$ & 2018 & deltamethrin \\
\hline Africa & South Africa & Ntondini et al., ${ }^{55}$ & 2008 & Amitraz \\
\hline Africa & South Africa & Ntondini et al., ${ }^{55}$ & 2008 & Cypermethrin \\
\hline Africa & South Africa & Ntondini et al., ${ }^{55}$ & 2008 & chlorfenvinphos \\
\hline Africa & South Africa & Baron et al.., ${ }^{56}$ & 2015 & Amitraz \\
\hline Africa & South Africa & Lovis et al., ${ }^{57}$ & 2013 & Pyriprol \\
\hline Africa & South Africa & Lovis et al., ${ }^{57}$ & 2013 & Cypermethrin \\
\hline Africa & South Africa & Lovis et al., ${ }^{57}$ & 2013 & fenvalerate \\
\hline Africa & Tanzania & Kagaruki $^{58}$ & 1991 & Dieldrin \\
\hline Africa & Tanzania & Kagaruki ${ }^{58}$ & 1991 & lindane \\
\hline Africa & Zambia & Muyobela et al., ${ }^{59}$ & 2015 & Amitraz \\
\hline Africa & Zambia & Muyobela et al., ${ }^{59}$ & 2015 & Cypermethrin \\
\hline S America & Argentina & Mangold et al., ${ }^{59}$ & 2004 & Flumethrin \\
\hline S America & Argentina & Cutullé et al., ${ }^{60}$ & 2013 & Amitraz \\
\hline
\end{tabular}


Table Continued...

\begin{tabular}{|c|c|c|c|c|}
\hline Continent & Country & Reference & Year & Acaricide or active ingredient \\
\hline S America & Argentina & Cutullé et al., 60 & 2013 & Cypermethrin \\
\hline S America & Argentina & Cutullé et al., ${ }^{60}$ & 2013 & Flumethrin \\
\hline S America & Argentina & Lovis et al.,.61 & 2013 & Amitraz \\
\hline S America & Argentina & Lovis et al.,61 & 2013 & Cypermethrin \\
\hline S America & Argentina & Lovis et al.., ${ }^{61}$ & 2013 & Flumethrin \\
\hline S America & Argentina & Cutullé et al., ${ }^{60}$ & 2013 & Amitraz \\
\hline S America & Argentina & Cutullé et al., ${ }^{60}$ & 2013 & deltamethrin \\
\hline S America & Bolivia & Villarroel-Alvarez et al.. ${ }^{62}$ & 2006 & Flumethrin \\
\hline S America & Bolivia & Villarroel-Alvarez et al.. ${ }^{62}$ & 2006 & deltamethrin \\
\hline S America & Bolivia & Villarroel-Alvarez et al., ${ }^{62}$ & 2006 & Cypermethrin \\
\hline S America & Brazil & Martins \& Furlong ${ }^{63}$ & 2001 & Doramectin \\
\hline S America & Brazil & Martins \& Furlong ${ }^{63}$ & 2001 & moxidectina \\
\hline S America & Brazil & Li et al.. ${ }^{64}$ & 2004 & Amitraz \\
\hline S America & Brazil & Klafke et al.., ${ }^{6}$ & 2006 & Ivermectin \\
\hline S America & Brazil & Mendes et al.. ${ }^{65}$ & 2007 & Cypermethrin \\
\hline S America & Brazil & Mendes et al.. ${ }^{65}$ & 2007 & deltamethrin \\
\hline S America & Brazil & Mendes et al.. ${ }^{65}$ & 2007 & Chlorpyriphos \\
\hline S America & Brazil & Castro-Janer et al., ${ }^{49}$ & 2010 & Fipronil \\
\hline S America & Brazil & Klafke et al.., ${ }^{6}$ & 2010 & Ivermectin \\
\hline S America & Brazil & Klafke et al.., ${ }^{6}$ & 2011 & Ivermectin \\
\hline S America & Brazil & Andreotti et al. ${ }^{66}$ & 2011 & Alpha-cypermethrin \\
\hline S America & Brazil & Andreotti et al..,6 & 2011 & Cypermethrin \\
\hline S America & Brazil & Andreotti et al.., ${ }^{66}$ & 2011 & Amitraz \\
\hline S America & Brazil & Mendes et al.., ${ }^{67}$ & 2011 & Deltamethrin \\
\hline S America & Brazil & Mendes et al.., ${ }^{67}$ & 2011 & Chlorpyriphos \\
\hline S America & Brazil & Mendes et al.., ${ }^{67}$ & 2011 & Cypermethrin \\
\hline S America & Brazil & Reck et al.., ${ }^{68}$ & 2014 & Chlorpyriphos \\
\hline S America & Brazil & Reck et al..68 & 2014 & Amitraz \\
\hline S America & Brazil & Reck et al.., ${ }^{68}$ & 2014 & Cypermethrin \\
\hline S America & Brazil & Reck et al.,.68 & 2014 & fipronil \\
\hline S America & Brazil & Reck et al..,68 & 2014 & Ivermectin \\
\hline S America & Brazil & Reck et al.., ${ }^{68}$ & 2014 & Fluazuron \\
\hline S America & Brazil & Klafke et al.., ${ }^{6}$ & 2016 & Amitraz \\
\hline S America & Brazil & Klafke et al.., ${ }^{6}$ & 2016 & Chlorpyriphos \\
\hline S America & Brazil & Klafke et al.., ${ }^{6}$ & 2016 & Cypermethrin \\
\hline S America & Brazil & Klafke et al., ${ }^{6}$ & 2016 & Fipronil \\
\hline S America & Brazil & Klafke et al.., ${ }^{6}$ & 2016 & ivermectin \\
\hline S America & Colombia & Benavides et al.,69 & 2000 & Cypermethrin \\
\hline S America & Colombia & Benavides et al.,69 & 2000 & deltamethrin \\
\hline S America & Colombia & Benavides et al.,69 & 2000 & coumaphos \\
\hline S America & Colombia & Benavides et al., 69 & 2000 & chlorfenvinphos \\
\hline
\end{tabular}


Table Continued...

\begin{tabular}{|c|c|c|c|c|}
\hline Continent & Country & Reference & Year & Acaricide or active ingredient \\
\hline S America & Colombia & Benavides et al., ${ }^{69}$ & 2000 & diazinon \\
\hline S America & Colombia & Benavides et al.,69 & 2000 & Amitraz \\
\hline S America & Colombia & Diaz \& Vallejo ${ }^{70}$ & 2013 & Cypermethrin \\
\hline S America & Colombia & Lopez-Arias et al.,"1 & 2014 & Cypermethrin \\
\hline S America & Colombia & Lopez-Arias et al., ${ }^{71}$ & 2014 & Amitraz \\
\hline S America & Colombia & Araque et al.., ${ }^{72}$ & 2014 & Amitraz \\
\hline SAmerica & Colombia & Araque et al., ${ }^{72}$ & 2014 & ethion \\
\hline S America & Colombia & Puerta et al.,43 & 2015 & Cypermethrin \\
\hline S America & Colombia & Puerta et al.,43 & 2015 & Amitraz \\
\hline S America & Colombia & Villar et al., ${ }^{73}$ & $2016 a$ & Ivermectin \\
\hline S America & Colombia & Villar et al.. ${ }^{74}$ & $2016 b$ & Deltamethrin \\
\hline S America & Colombia & Villar et al. ${ }^{74}$ & $2016 b$ & Amitraz \\
\hline S America & Colombia & Villar et al., ${ }^{74}$ & $2016 b$ & Chlorpyriphos \\
\hline NAmerica & Costa Rica & Hagen et al.., 75 & 1999 & Flumethrin \\
\hline N America & Costa Rica & Alvarez \& Hernandez ${ }^{76}$ & 2010 & Chlorpyriphos \\
\hline NAmerica & Costa Rica & Alvarez \& Hernandez ${ }^{76}$ & 2010 & coumaphos \\
\hline N America & Costa Rica & Alvarez \& Hernandez ${ }^{76}$ & 2010 & Flumethrin \\
\hline N America & Costa Rica & Alvarez \& Hernandez ${ }^{76}$ & 2010 & deltamethrin \\
\hline N America & Costa Rica & Alvarez \& Hernandez ${ }^{76}$ & 2010 & ivermectin \\
\hline N America & Costa Rica & Alvarez \& Hernandez ${ }^{76}$ & 2010 & Amitraz \\
\hline N America & Cuba & Valdez et al.., ${ }^{77}$ & 1999 & Chlorfenvinphos Cyamizol \\
\hline N America & El Salvador & Hagen et al.., ${ }^{75}$ & 1999 & Flumethrin \\
\hline N America & Guatemala & Hagen et al.., ${ }^{75}$ & 1999 & Deltamethrin \\
\hline NAmerica & Guatemala & Hagen et al.. ${ }^{75}$ & 1999 & Flumethrin \\
\hline N America & Guatemala & Hagen et al., ${ }^{75}$ & 1999 & cyfluthrin \\
\hline N America & Jamaica & Rawlins \& Mansingh ${ }^{78}$ & 1978 & Carbaryl \\
\hline N America & Jamaica & Rawlins \& Mansingh ${ }^{78}$ & 1978 & Lindane \\
\hline NAmerica & Jamaica & Rawlins \& Mansingh ${ }^{78}$ & 1978 & chlorfenvinphos \\
\hline NAmerica & México & Ortiz et al.,. ${ }^{79}$ & 1995 & Dieldrin \\
\hline N America & México & Ortiz et al.., ${ }^{79}$ & 1995 & Cypermethrin \\
\hline NAmerica & México & Ortiz et al.,.99 & 1995 & deltamethrin \\
\hline N America & México & Ortiz et al.., ${ }^{79}$ & 1995 & Lindane \\
\hline NAmerica & México & Ortiz et al..,79 & 1995 & coumaphos \\
\hline N America & México & Ortiz et al.,. ${ }^{79}$ & 1995 & diazinon \\
\hline N America & México & Ortiz et al.,. ${ }^{79}$ & 1995 & dioxathion \\
\hline N America & México & Ortiz et al.,. ${ }^{79}$ & 1995 & dimethoate \\
\hline N America & México & Ortiz et al..,79 & 1995 & ethion \\
\hline N America & México & Fragoso et al.. ${ }^{80}$ & 1995 & Amitraz \\
\hline N America & México & Soberanes et al.., ${ }^{81}$ & 2002 & Amitraz \\
\hline N America & México & Li et al.., ${ }^{64}$ & 2004 & Carbaryl \\
\hline NAmerica & México & Rodriguez-Vivas et al.,.2 & $2006 \mathrm{~b}$ & Amitraz \\
\hline
\end{tabular}


Table Continued..

\begin{tabular}{|c|c|c|c|c|}
\hline Continent & Country & Reference & Year & Acaricide or active ingredient \\
\hline NAmerica & México & Rodríguez-Vivas et al., ${ }^{83}$ & 2007 & Diazinon \\
\hline N America & México & Rodríguez-Vivas et al.., ${ }^{83}$ & 2007 & coumaphos \\
\hline N America & México & Rodríguez-Vivas et al., & 2007 & chlorfenvinphos \\
\hline N America & México & Rodríguez-Vivas et al., ${ }^{83}$ & 2007 & Flumethrin \\
\hline N America & México & Rodríguez-Vivas et al., ${ }^{83}$ & 2007 & deltamethrin \\
\hline N America & México & Rodríguez-Vivas et al., ${ }^{83}$ & 2007 & Cypermethrin \\
\hline N America & México & Rosado-Aguilar et al., ${ }^{84}$ & 2008 & Amitraz \\
\hline N America & México & Fernández-Salas et al., ${ }^{85}$ & $2012 c$ & Cypermethrin \\
\hline NAmerica & México & Fernández-Salas et al., ${ }^{86}$ & $2012 b$ & Diazinon \\
\hline N America & México & Fernández-Salas et al., ${ }^{86}$ & $2012 b$ & Flumethrin \\
\hline NAmerica & México & Fernández-Salas et al., & $2012 b$ & deltamethrin \\
\hline NAmerica & México & Fernández-Salas et al., & $2012 b$ & Cypermethrin \\
\hline NAmerica & México & Perez-Cogollo et al., ${ }^{87}$ & $2010 a$ & Ivermectin \\
\hline N America & México & Rodríguez-Vivas et al., & 2011 & Cypermethrin \\
\hline N America & México & Olivares-Pérez et al., ${ }^{89}$ & 2011 & Amitraz \\
\hline N America & México & Olivares-Pérez et al., ${ }^{89}$ & 2011 & Flumethrin \\
\hline N America & México & Olivares-Pérez et al., ${ }^{89}$ & 2011 & deltamethrin \\
\hline N America & México & Olivares-Pérez et al., ${ }^{89}$ & 2011 & Cypermethrin \\
\hline NAmerica & México & Olivares-Pérez et al., ${ }^{89}$ & 2011 & Chlorpyriphos \\
\hline N America & México & Olivares-Pérez et al., ${ }^{89}$ & 2011 & coumaphos \\
\hline N America & México & Olivares-Pérez et al., ${ }^{89}$ & 2011 & diazinon \\
\hline N America & México & Miller et al., ${ }^{90}$ & 2013 & Fipronil \\
\hline N America & México & Rodríguez-Vivas et al.," & 2013 & Ivermectin \\
\hline N America & México & Rodríguez-Vivas et al.,9' & 2013 & Amitraz \\
\hline N America & México & Rodríguez-Vivas et al.,"' & 2013 & Chlorpyriphos \\
\hline NAmerica & México & Rodríguez-Vivas et al.," & 2013 & coumaphos \\
\hline NAmerica & México & Rodríguez-Vivas et al., ${ }^{91}$ & 2013 & Cypermethrin \\
\hline NAmerica & México & Rodríguez-Vivas et al.," & 2013 & permethrin \\
\hline N America & México & Rodríguez-Vivas et al.,91 & 2013 & fipronil \\
\hline N America & Panama & Hagen et al., ${ }^{75}$ & 1999 & Flumethrin \\
\hline N America & Panama & Torrijos et al., ${ }^{92}$ & 2015 & Cypermethrin \\
\hline N America & Dominican Republic & Hagen et al., ${ }^{75}$ & 1999 & Deltamethrin \\
\hline NAmerica & Dominican Republic & Hagen et al., ${ }^{75}$ & 1999 & Flumethrin \\
\hline NAmerica & Dominican Republic & Hagen et al., ${ }^{75}$ & 1999 & cyfluthrin \\
\hline S America & Uruguay & Castro-Janer et al., ${ }^{93}$ & 2009 & Fipronil \\
\hline S America & Uruguay & Castro-Janer et al., ${ }^{94}$ & 2011 & Ivermectin \\
\hline S America & Uruguay & Cuore \& Solari ${ }^{95}$ & 2014 & Ethion \\
\hline S America & Uruguay & Cuore \& Solari ${ }^{95}$ & 2014 & Cypermethrin \\
\hline S America & Uruguay & Cuore \& Solari ${ }^{95}$ & 2014 & Amitraz \\
\hline S America & Uruguay & Cuore \& Solari ${ }^{95}$ & 2014 & fipronil \\
\hline S America & Uruguay & Cuore \& Solari ${ }^{95}$ & 2014 & ivermectin \\
\hline
\end{tabular}


Table Continued..

\begin{tabular}{|c|c|c|c|c|}
\hline Continent & Country & Reference & Year & Acaricide or active ingredient \\
\hline S America & Uruguay & Castro-Janer et al., ${ }^{96}$ & 2015 & Fipronil \\
\hline S America & Uruguay & Castro-Janer et al., ${ }^{96}$ & 2015 & Lindane \\
\hline N America & USA & Miller et al., ${ }^{97}$ & $2007 b$ & Permethrin \\
\hline N America & USA & Busch et al., ${ }^{98}$ & 2014 & Coumaphos \\
\hline N America & USA & Busch et al., ${ }^{98}$ & 2014 & permethrin \\
\hline NAmerica & USA & Busch et al., ${ }^{98}$ & 2014 & Amitraz \\
\hline NAmerica & USA & Busch et al., ${ }^{98}$ & 2014 & ivermectin \\
\hline N America & USA & Busch et al., ${ }^{98}$ & 2014 & fipronil \\
\hline N America & USA & Klafke et al., ${ }^{6}$ & 2017 & permethrin \\
\hline N America & USA & Klafke et al., ${ }^{6}$ & 2017 & Cypermethrin \\
\hline NAmerica & USA & Klafke et al., ${ }^{6}$ & 2017 & deltamethrin \\
\hline N America & USA & Klafke et al., ${ }^{6}$ & 2017 & Flumethrin \\
\hline S America & Venezuela & Coronado99 & 1999 & Amitraz \\
\hline Asia & India & Chaudhuri \& Naithani ${ }^{100}$ & 1964 & $\mathrm{BHC}$ \\
\hline Asia & India & Kumar et al., ${ }^{101}$ & 2011 & Diazinon \\
\hline Asia & India & ALT Sharma et al., ${ }^{102}$ & 2012 & Deltamethrin \\
\hline Asia & India & ALT Sharma et al., ${ }^{102}$ & 2012 & Cypermethrin \\
\hline Asia & India & Shyma et al., ${ }^{103}$ & 2013 & Deltamethrin \\
\hline Asia & India & Shyma et al., ${ }^{103}$ & 2013 & Cypermethrin \\
\hline Asia & India & Shyma et al., ${ }^{103}$ & 2013 & diazinon \\
\hline Asia & India & Singh et al., ${ }^{104}$ & 2014 & Cypermethrin \\
\hline Asia & India & Jyoti Singh et al., ${ }^{105}$ & 2014 & Malathion \\
\hline Asia & India & Singh et al., ${ }^{106}$ & 2015 & Amitraz \\
\hline Asia & India & Ghosh et al., ${ }^{107}$ & 2015 & Deltamethrin \\
\hline Asia & India & Ghosh et al., ${ }^{107}$ & 2015 & diazinon \\
\hline Asia & India & Shyma et al., ${ }^{108}$ & 2015 & Deltamethrin \\
\hline Asia & India & Shyma et al., ${ }^{108}$ & 2015 & fipronil \\
\hline Asia & India & Shyma et al.., ${ }^{108}$ & 2015 & Flumethrin \\
\hline Asia & India & Gaur et al., ${ }^{109}$ & 2016 & Deltamethrin \\
\hline Asia & India & Gaur et al., ${ }^{109}$ & 2016 & diazinon \\
\hline Asia & India & Khangembam et al. ${ }^{51}$ & 2018 & ivermectin \\
\hline Asia & Iran & Ziapour et al.,' & 2016 & lambda-cyhalothrin \\
\hline Asia & Iran & Ziapour et al.,' & 2016 & Cypermethrin \\
\hline Australia & Australia & Mackerras $^{53}$ & 1936 & arsenic tetroxide \\
\hline Australia & Australia & Stone \&Webber ${ }^{110}$ & 1960 & $\mathrm{BHC}$ \\
\hline Australia & Australia & Stone \&Webber ${ }^{110}$ & 1960 & DDT \\
\hline Australia & Australia & Stone $\&$ Webber ${ }^{110}$ & 1960 & dieldrin \\
\hline Australia & Australia & Stone \& Meyers ${ }^{110}$ & 1957 & Dieldrin \\
\hline Australia & Australia & Shaw ${ }^{\prime \prime \prime}$ & 1966 & Carbophenothion \\
\hline Australia & Australia & Shaw ${ }^{\prime \prime \prime}$ & 1966 & dioxathion \\
\hline
\end{tabular}




\begin{tabular}{|c|c|c|c|c|}
\hline Continent & Country & Reference & Year & Acaricide or active ingredient \\
\hline Australia & Australia & Shaw ${ }^{\prime \prime \prime}$ & 1966 & diazinon \\
\hline Australia & Australia & Shaw'"l & 1966 & parathion \\
\hline Australia & Australia & Shaw'"I & 1966 & carbaryl \\
\hline Australia & Australia & Nolan et al., ${ }^{112}$ & 1989 & Cypermethrin \\
\hline Australia & Australia & Nolan et al., ${ }^{112}$ & 1989 & cyhalothrin \\
\hline Australia & Australia & Roulston et al., ${ }^{113}$ & 1981 & Dimethoate \\
\hline Australia & Australia & Roulston et al., ${ }^{113}$ & 1981 & dioxathion \\
\hline Australia & Australia & Roulston et al., ${ }^{113}$ & 1981 & coumaphos \\
\hline Australia & Australia & Roulston et al., ${ }^{113}$ & 1981 & cyanophos \\
\hline Australia & Australia & Roulston et al., ${ }^{113}$ & 1981 & Chlorpyriphos \\
\hline Australia & Australia & Roulston et al., ${ }^{113}$ & 1981 & dieldrin \\
\hline Australia & Australia & Roulston et al., ${ }^{113}$ & 1981 & DDT \\
\hline Australia & Australia & Jonsson \& Hope ${ }^{1 / 4}$ & 2007 & Amitraz \\
\hline Australia & Australia & Lovis et al.,.57 & 2013 & Flumethrin \\
\hline Australia & Australia & Lovis et al.,.57 & 2013 & Cypermethrin \\
\hline Australia & Australia & Lovis et al.., ${ }^{57}$ & 2013 & pyriprol \\
\hline Australia & New Caledonia & Brun et al., ${ }^{115}$ & 1983 & Ethion \\
\hline Australia & New Caledonia & Beugnet \& Chardonnet ${ }^{116}$ & 1995 & Fenvalerate \\
\hline Australia & New Caledonia & Beugnet \& Chardonnet ${ }^{116}$ & 1995 & deltamethrin \\
\hline Australia & New Caledonia & Beugnet \& Chardonnet ${ }^{116}$ & 1995 & Flumethrin \\
\hline Australia & New Caledonia & Bianchi et al., ${ }^{117}$ & 2003 & Deltamethrin \\
\hline Australia & New Caledonia & Bianchi et al., ${ }^{117}$ & 2003 & ethion \\
\hline Australia & New Caledonia & Ducornez et al.., ${ }^{118}$ & 2005 & Amitraz \\
\hline Australia & New Caledonia & Petermann et al.," ${ }^{\prime 19}$ & 2016 & deltamethrin \\
\hline Australia & New Caledonia & Petermann et al., 119 & 2016 & Amitraz \\
\hline
\end{tabular}

The latest reports on resistance in $R$. (B.) microplus include resistance to deltamethrin, where the use of the recommended dose (200 ppm) caused $33.33 \%$ mortality in ticks, and the application of double the recommended dose caused 56\% mortality, while for the use of ivermectin, there are high resistance factors in treatments performed both in the laboratory and in the field. ${ }^{50,51}$ These and other reports on ticks with resistance to different chemical acaricide formulations elucidate the difficulty that comes with the development of new molecules capable of exercising efficient control. ${ }^{120}$

\section{Factors that lead to the development of resistance}

The FAO, in 2013, ${ }^{121}$ established that the development of resistance is not only linked to operational factors but is also largely due to genetic and biological factors of the pest. In arthropods, development is partly dependent on factors related to the use of acaricides and the life cycle of the organism. ${ }^{122}$ Therefore, internal and external factors influence the development of resistance in $R$. (B.) microplus.

Biological factors refer to the duration of the life cycle, population densities, reproductive capacity, type of reproduction and host range of the pest. ${ }^{121} R$. (B.) microplus, which is a single host tick, has a shorter life cycle than the ticks of several hosts and produces a high amount of eggs, which means that this species produces a greater number of offspring annually. Therefore, a large variety of acaricides is needed to effectively control infestations, ${ }^{122}$ resulting in a high potential for resistance development.

A clear explanation of the operational activities that lead to the development of resistance in cattle ticks was given by Vudriko et al. ${ }^{123}$, who reported that Ugandan producers employ activities that are not effective in the long term, with an increase of 2 to 4 times the concentrations in applications and an increase in the frequency of the use of acaricides, along with mixing two or more acaricides and not correctly rotating the products that are used, activities that are contrary to the integrated management approach for pests as presented by the Insecticide Resistance Action Committee ${ }^{47}$ and the FAO for several years.

Rodríguez-Vivas et al., ${ }^{52}$ studied the genetic behavior of resistance in $R$. (B.) microplus according to phenotype and genotype, following the distinction made by Guerrero et al., ${ }^{122}$ who established that the resistant phenotype is given by the susceptibility or resistance of a group of individuals to the effects of an application of a certain acaricide, while the resistance genotype refers to the genetic composition of the tick, which leads to the expression of the resistance phenotype. 
These genetic factors occur because of the modification of a specific gene or group of genes linked to responses that will prevent the expected acaricidal effect from occurring in the pest. ${ }^{121}$ In order to understand the way in which genetics acts in the development of different types of resistance, studies have been carried out that associate genetic alterations with the resistance mechanism.

\section{Resistance mechanisms}

Genetic changes promote the development of resistance in tick populations. These changes generate resistance mechanisms in individuals, described as follows: modifications at the target site, increased metabolism, acaricide sequestration, or reduced ability of acaricide to penetrate through the outer protective layers of the tick body (Table 4). ${ }^{122}$

In the identification of resistance mechanisms in $R$. (B) microplus, there have been advances that show the way in which the enzymatic, metabolic, genetic and proteomic activities are involved (Table 4). There are also reports that have demonstrated the presence of combinations of different resistance mechanisms. ${ }^{96,125,126,6}$ This type of resistance is known as "cross resistance," which occurs when a single defense mechanism against an insecticide also confers resistance to other insecticides, even if the insect has not been previously exposed to the other products. ${ }^{130}$

Table 4 Types of resistance generated by $R$. (B.) microplus

\begin{tabular}{|c|c|c|}
\hline $\begin{array}{l}\text { Resistance } \\
\text { mechanism }\end{array}$ & \multicolumn{2}{|l|}{ Definition } \\
\hline $\begin{array}{l}\text { Metabolic } \\
\text { detoxification } \\
\text { (enzymatic) }\end{array}$ & \multicolumn{2}{|c|}{$\begin{array}{l}\text { Development of high levels of a particular enzyme or altered forms } \\
\text { of it with higher catalytic rates, which eliminate naturally occurring } \\
\text { toxins in hosts, these enzymes include esterases, cytochrome P450 } \\
\text { monooxygenases, and glutathione S-transferases. }{ }^{124}\end{array}$} \\
\hline \multirow{3}{*}{$\begin{array}{l}\text { Reduced } \\
\text { sensitivity at } \\
\text { the site of } \\
\text { action }\end{array}$} & $\begin{array}{l}\text { Change of pesticide fixation } \\
\text { site, eliminating or significantly } \\
\text { reducing effectiveness }^{|2|}\end{array}$ & $\begin{array}{l}\text { KDR (shock resistance): sodium } \\
\text { channel interference in nerve } \\
\text { cells. Commonly developed } \\
\text { in resistance to DDT and } \\
\text { pyrethroids. }{ }^{47}\end{array}$ \\
\hline & & $\begin{array}{l}\text { MACE (modified } \\
\text { acetylcholinesterase): } \\
\text { modifies the structure of } \\
\text { acetylcholinesterase so that } \\
\text { it is no longer affected by the } \\
\text { insecticide. }^{|2|}\end{array}$ \\
\hline & & $\begin{array}{l}\text { RDL (resistance to dieldrin) is a } \\
\text { mutation point that reduces the } \\
\text { binding of dieldrin to the GABA } \\
\text { receptor. }{ }^{49}\end{array}$ \\
\hline
\end{tabular}

Metabolic enzymes increase considerably (up to I5\% of the total

Sequestration body of the protein) and fixed to the insecticide, but the insecticide is not metabolized, that is, it is not sequestered. ${ }^{122}$

The modification of the behavior helps to avoid the lethal effect of

Behavioral the pesticides since feeding simply stops if the individual becomes close to some insecticides or can leave the area that has been treated. ${ }^{126}$

This mechanism retards the penetration of the pesticide through

Reduced the cuticle of resistant insects, producing low levels of resistance, penetration

\section{Resistance studies on R. B. microplus}

Increase in the activity of the enzymes $\beta$-naphthol, $\beta$-esterase and cytochrome P450, in pyrethroid, organophosphorus and phenylpyrazole resistant ticks. ${ }^{25}$

Mutations in the s4-5 gene of domain II of the sodium channel, given by conversion of glycine to valine at position 72 , generate resistance to DDT and malathion ${ }^{126}$

Development of resistance to organophosphorus by modified acetylcholinesterase as a result of fluctuations in the increase in transcription of the achE2 and pAChE2 genes ${ }^{48}$

Alanine substitutions (A286S / L) in populations resistant to fipronil $^{49}$

The study of behavioral resistance in R. (B). microplus has not been addressed, however Soares \& Borges, ${ }^{127}$ studied the behavior of Amblyomma Cajennense, identifying sensory odor neurons that presented positive responses (movement towards) to 2,6-dichlorophenol (2,6-DCP)

Kluck et al., ${ }^{128}$ verified the presence of a candidate hemolymphatic protein, called Rhipicephalus microplus lipid carrier protein (RmLCP), this lipoprotein binds and transports free cholesterol and is presumed to be involved in lipid modification that promotes reduced penetration resistance

\section{Use of bio-extracts for the control of R. (B.) microplus}

This species has been a favorite organism for evaluating different types of extracts worldwide, given its distribution and importance in animal and human health. Therefore, these evaluations are based on the effect that these extracts produce in adult, nymph and larval mortality, along with the effect on oviposition and hatching. ${ }^{12}$
There is a global trend to reduce the use of chemical insecticides and acaricides, mainly caused by the development of resistance and the presence of traces of chemical residues in food that damage human and animal health, The loss of biodiversity and ecosystem degradation, and costs are other drawbacks of the use of acaricides. ${ }^{8}$

Therefore, in order to control tick infestations, alternatives for their control have been developed, based on the use of plants that are 
recognized for their antiparasitic characteristics ${ }^{131}$ and that generally have a lower value and are safer and more friendly to the environment, promoting interest in the use and study of extracts obtained from these plants. ${ }^{132}$

Worldwide there is a wide variety of plant extracts of various species, prepared through different methodologies that use leaves, roots, stems, flowers, fruits and seeds, obtaining extracts based on water, ${ }^{9,131}$ oil $^{133}$ or different types of alcohols. ${ }^{11,132,134}$ Essential oils have been obtained and used ${ }^{135,136}$ in spray dried powder ${ }^{6}$ for the control of this important ectoparasite

According to a review by Adenubi et al. ${ }^{8}$ in the use of plant extracts for the control of different species of ticks worldwide from 1914 to 2014, 30 species of plants were used. Two years later, Adenubi et al., ${ }^{12}$ found that the number of species used for the elaboration of extracts with a tick effect increased from 30 to 55. These extracts are distributed as follows: according to the families to which they belong: Lamiaceae 20\%, Asteraceae 13\%, Rutaceae and Fabaceae 9\% and Solanaceae $7 \%$. This study clarified that, of the studies conducted on bio-extracts for the control of ticks, only $17 \%$ focused on how these extracts act or their mode of action, which should be addressed since this information theoretically and scientifically reinforces the use of plant extracts in the control of pests and diseases.

\section{Coumarins as an alternative in the control of} R. (B.) microplus

The presence of secondary metabolites that are related to the control of ticks has been evidenced from plant extracts, including flavonoids, terpenes, spilanthol and coumarins. ${ }^{13,137-139}$ The latter are the most important within this document since they are one of the largest classes of natural compounds and are present in many plants as secondary metabolites in roots, stems, leaves, branches and seeds. ${ }^{140}$

\section{Development and employment of coumarins}

Coumarins have been thoroughly studied because of their potential for fighting diseases and pests, both in plants and animals, and their anti-inflammatory, antioxidant, antimicrobial, antiviral, anticoagulant and anticancer activities. ${ }^{141,142}$ This family of secondary plant-derived metabolites was first isolated in 1820 by Voguel from a Fabaceae called Coumarouna odorata, now known as Dipteryx odorata, commonly known as cumarú. ${ }^{142}$ Its main use was the cosmetic industry. ${ }^{143}$

It took 40 years for Perkin in 1868 to design a reaction using salicylaldehyde and acetic anhydride to synthesize coumarin, a methodology that is still used today. ${ }^{142}$ In 1947 , Seshadri \& Murti ${ }^{144}$ compared coumarin derivatives to natural flavones to reveal the level of toxicity of these compounds because they had previously been associated with hemorrhagic diseases in cattle, resulting in 3-phenyl and 4-phenylumbelliferone and its methyl esters, which are highly toxic in fish. By 1948, the efforts of Karl Link ${ }^{145}$ and his collaborators took the use of coumarins a step further when warfarin (3-phenylacetyl ethyl, 4-hydroxycoumarin) was isolated from coumarin compounds, which was used as rodenticide, the most potent form of synthetic coumarins at the time. ${ }^{146}$ Warfarin, in addition to being used for rodenticide, was also included in the prevention of thromboembolic diseases, demonstrating greater efficiency than dicumarol and heparins. ${ }^{147}$

On March 5, 1954, the use of coumarins in food ${ }^{148}$ was regulated because liver diseases related to high doses of coumarins were reported, where prolonged doses of $2500 \mathrm{ppm}$ caused pathologies in the livers of mice. ${ }^{149,150}$ In the 1960 s, significant advances were reported for the use of different types of coumarins as growth regulators in plants, such as antispasmodic and analgesic agents, breathing stimulants, vasodilators, antibacterial, anthelmintic, and antifungal agents, and insecticides; ${ }^{151}$ many others are still studied today. The study of biosynthetic routes for coumarins began with Kosuge \& Conn in $1959,{ }^{152}$ who demonstrated that the shikimic acid route is the pathway for the metabolization of o-coumaric acid, which is a precursor of Coumarins and is associated with the synthesis of the aromatic ring of the molecule. Another study was carried out by Brown during the 60 s and 70 s that focused on the study of the biosynthetic routes of coumarins, conducting experiments that identified precursors involved in the formation of coumarins, such as L-phenylalanine and p-coumaric acid, and pointing out reactions such as methylation, lactonization, and hydroxylation, among others. ${ }^{153,154}$

Parallel to these investigations and as the result of the development of resistance to the use of these compounds in anticoagulant treatments and in the use as rodenticide, from 1975 to 1978 , the second generation of coumarins was developed, ${ }^{155}$ which were based on the replacement of stereochemically similar side chains in the 4 hydroxycoumarin, known as difenacoum and brodifacoum. ${ }^{156}$ In the late 1980 s, research on coumarins focused on new ways of synthesizing the molecule and its use in medicine, with contributions from Harvey et al. ${ }^{157}$ who, in 1988, developed a new type of synthesis based on Ortho-directed methylation, obtaining a series of coumarins with substituents in positions 6 and 7, which were used in bioassays to reveal their antitumor activity, resulting in polycyclic coumarins with a chemo preventive cancer activity.

By 2002, Lake et al., ${ }^{158}$ demonstrated with live studies in both mice and Drosophila melanogaster that coumarin compounds are not genotoxic agents. However, in vitro tests on human liver cultures with high doses of coumarins resulted in genotoxicity. Kostova ${ }^{159}$ reported a considerable number of tests carried out in vivo and in vitro on cytotoxicity related to the use of coumarins, which may present a greater or lesser degree of cytotoxicity according to the type of substituent that is used. ${ }^{160}$

Research on the possible uses and characteristics of coumarins are still valid. In fact, there are a large number of reports aimed at alternative uses of coumarins; more than 1300 coumarins have been isolated from plants, bacteria and fungi, ${ }^{14-16}$ with antioxidant, ${ }^{161}$ anti$\mathrm{HIV},{ }^{162}$ anticancer ${ }^{163}$ antiviral, ${ }^{164}$ antituberculosis, ${ }^{165}$ insecticide and fungicide properties, ${ }^{166}$ among others.

\section{Obtaining coumarins}

\section{Natural coumarins}

Coumarins occur naturally in plants. These secondary metabolites are associated with defense functions against fungi and insects, Coumarin compounds are a class of lactones structurally constructed by a benzene ring fused with an $\alpha$-pyrone ring. ${ }^{167}$

Coumarins are naturally synthesized phenolic compounds, through the shikimic acid pathway. This metabolic pathway occurs from the reaction of 1-phenylalanine, which is catalyzed by the enzyme phenylalanine ammonium lyase (PAL), resulting in cinnamic acid. Once this acid has been formed, a series of reactions that includes hydroxylation, methylation and dehydration occurs, the most important being the reactions that take place in the ortho and para positions, which in turn involve processes in which enzymes intervene, such as cinnamate 4 hydroxylase, in the putative P450 
and P450 metabolic pathways, along with the independent routes of these enzymes and others, in which the lactonization process occurs, resulting in various types of coumarins. ${ }^{168,169}$

Voguel, in 1820, was the first to report the successful extraction of coumarins from Dipteryx odorata: ${ }^{142,151}$ however, it was not until years later that the methodologies for obtaining them were known, ${ }^{170}$ using different species of plants ${ }^{146}$ and different plant parts. These methodologies are based on obtaining plant extracts from the maceration of plant material and the addition of solvents of increasing polarity, such as petroleum ether and bicarbonate or sodium carbonate, which then allow direct crystallization from the concentrated extract, either during Soxhlet extraction or at rest at a higher concentration and cooling of the extract. ${ }^{171}$

Currently, the isolation of coumarins is carried out with techniques that combine different types of maceration, either using ultrasound, liquid nitrogen, infusions, or solvents of different polarities, such as hexane, chloroform, ethyl acetate and methanol, resulting in concentrates with vacuum distillation using Soxhlet, supercritical CO2 extraction, ${ }^{172}$ pressurized hot water extraction, ${ }^{173}$ microwave-assisted extraction, ${ }^{174}$ or dispersion in the solid phase of the effervescenceassisted matrix (EA-MSPD). ${ }^{175}$

\section{Synthesis of coumarins}

Research developed with the objective of synthesizing new coumarins has been widely addressed. The first methodology for obtaining coumarins was proposed by Perkin in $1868 .{ }^{142}$ Perkin used different temperatures, an alkaline salt as a catalyst, and acetic acid, which resulted in a type of aldol condensation from an interaction between a carbanion and a carboxyl group. ${ }^{176,177}$ This was followed by methodologies such as condensation by Knoevenagel, which used the reaction between an aldehyde or its derivative and an ester, in the presence of the amine as a catalyst. This reaction synthesizes coumarins through cyclisation of the lactone group without the presence of solvents in processes carried out with microwaves ${ }^{178}$ or the Reformatsky reaction, which generates the condensation of aldehydes (or ketones) with $\alpha$-halo esters in the presence of metallic zinc, forming $\beta$-hydroxy esters that are dehydrated in subsequent steps to produce an unsaturated ester. ${ }^{179,180}$

On the other hand, the Wittig reaction synthesizes an alkene from the reaction of an aldehyde or ketone with the ilium generated from a phosphonium salt. ${ }^{181}$ Claisen also developed a decarboxylative condensation reaction, where, starting from an ester and a strong base used as a catalyst, a single carbon-carbon bond is produced. ${ }^{182}$ Pechmann used the esterification/transesterification of phenols with $\beta$-ketoesters with acids such as Bronsted or Lewis. ${ }^{183,184}$ These methodologies laid the foundation for the development of processes that obtain coumarin compounds. ${ }^{171}$ These new methodologies are based on the use of different reactions and catalytic processes in which the precursors and materials used to obtain coumarins vary, involving ecological approaches, new technologies, such as microwaves ${ }^{184}$ and ultrasound, ${ }^{185}$ new catalysts, ${ }^{186,187}$ ecological solvents, ${ }^{188}$ reactions without Solvents ${ }^{189}$ and molecular coupling, ${ }^{190,191}$ among others, resulting in coumarins with greater yields and better activity, demonstrating the importance of coumarin compounds in different industries and providing coumarin derivatives in recent years that are much more easily obtained, economical and environmentally responsible.

\section{Use of coumarins for tick control}

Many of the extracts evaluated for the control of ticks use coumarns; hence, they are associated with the effect on ticks. The cases in which mortality and/or repellency were greater than $60 \%$ were compiled, given that this effect resulted from the direct use of coumarins or by the presence of coumarins in bio-extracts.

Tunón et al., ${ }^{192}$ evaluated an extract of Artemisia abrotanum obtained from toluene and the essential oil of Dianthus caryophyllum, which, based on identification with thin layer chromatography, contains coumarins. This extract produced $93 \%$ mortality rates in Ixodes ricinus nymphs after 4 hours from the start of the test.

Mortality values obtained from the use of Ocotea elegans essential oil in $R$. (B.) microplus larvae and adults were $70 \%$ mortality with a concentration of $100 \mathrm{mg} / \mathrm{ml}$ in the larvae and, in the adults, were greater than $60 \%$ with a concentration of $6.2 \mathrm{mg} / \mathrm{ml}$, along with $97 \%$ mortality at $25 \mathrm{mg} / \mathrm{ml}$. Although no coumarins were detected in the essential oil of Ocotea elegans, Figueiredo et al., ${ }^{138}$ it has been previously reported as containing them. ${ }^{193,194}$

It has been shown that the use of coumarins for the control of Rhipicephalus appendiculatus larvae has been successful, with up to $90 \%$ mortality when two types of coumarin compounds isolated from Acokanthera schimperi were mixed. ${ }^{17}$

On the other hand, Rosado-Aguilar et al., ${ }^{195}$ stated that studies on the effects of essential oils and extracts of plants with coumarins showed an efficacy of 5 to $100 \%$, with the genus Rhipicephalus being the most studied. In addition, tests on the inhibition of egg hatching showed efficiencies of $60-100 \%$, and tests on larvae and adults produced mortality of 5 to $100 \%$ and 60 to $100 \%{ }^{132}$ The results obtained by Dantas et al., ${ }^{132}$ and reported by Rosado-Aguilar et al., ${ }^{195}$ confirmed that coumarins are a promising alternative for the control of ticks that are susceptible and resistant to conventional acaricides.

\section{Mode of action of coumarins in ticks}

Whatever the mechanism of action of coumarins, the strength of their binding to the target is increased by additional interactions involving the substituents present in the coumarin scaffold. The type of substituents and the substitution pattern determine, along with the general binding energy and potency, the selective interactions of coumarin derivatives with specific objectives. ${ }^{170}$

The use of plants with high tannin contents and the presence of cumaronochromones ${ }^{196}$ causes darkening of the cuticle, lack of movement in the Malpighi tubes and hemorrhagic skin lesions in $R$. (B.) microplus adults. A possible mode of action in coumarins was evidenced in a study by Enan, ${ }^{197}$ who evaluated the behavior of Periplaneta americana after being treated with three essential oils with cinnamic alcohol, which has been associated with coumarins by Ntalli et al., ${ }^{198}$ resulting in some signs of toxicity, such as hyperactivity, followed by hyperextension of the legs and abdomen, then rapid immobilization and finally death, symptoms that were compared with treatments with induced octopamine, finding similar signs of toxicity.

\section{Conclusions}

Because of the capacity not only of this species but of other types of ticks to expand distribution worldwide, it is necessary to develop and subsequently implement strategies with high viability and easy acceptance by producers since the use of acaricides and control techniques based on chemical compounds have lost their level of effectiveness, causing an increase in costs in relation to the effectiveness in the control of this species.

The use of plant extracts obtained from different plant species through different techniques has proven promising for the control of $R$. (B.) microplus, demonstrating even better behavior than the 
active ingredients used today for the control of this pest; however, more research is needed for the point and mode of action that these extracts have on the individual, either at the biochemical, molecular, proteomic or physiological levels.

Although coumarins are present in several plant extracts obtained from different species, there are very few studied on their acaricidal activity, a topic of great interest for future research, which can take into account the methodologies and raw materials used for obtaining them and their mode of action in $R$. (B.) microplus since the effect they have depends on, among other things, their chemical structure.

\section{Acknowledgments}

The authors are thankful for the support of the Grupo de Investigación en Bioquímica y Nutrición Animal - GIBNA of the Universidad Pedagógica y Tecnológica de Colombia.

\section{Conflicts of interest}

We declare that there is no conflict of interest that could be perceived as prejudicing the impartiality of the research reported.

\section{References}

1. Ziapour SP, Kheiri S, Asgarian F, et al. First report of pyrethroid resistance in Rhipicephalus (Boophilus) annulatus larvae (Say, 1821) from Iran Acta Tropica. 2016;156:22-29.

2. Nava S, Rossner MV, Ballent $M$, et al. Relationship between pharmacokinetics of ivermectin $(3.15 \%)$ and its efficacy to control the infestation with the tick Rhipicephalus (Boophilus) microplus in cattle. Veterinary Parasitology. 2019;268:81-86.

3. Dantas-Torres F, Chomel BB, Otranto D. Ticks and tick-borne diseases: a One Health perspective. Trends in Parasitology. 2012;28(10):437-446.

4. Ybañez AP, Mingala CN, Ybañez RHD. Historical review and insights on the livestock tick-borne disease research of a developing country: The Philippine scenario. Parasitology International. 2018;67(2):262-266.

5. Dantas-Torres F. Climate change, biodiversity, ticks and tick-borne diseases: The butterfly effect. International Journal for Parasitology: Parasites and Wildlife. 2015;4(3):452-461.

6. Klafke G, Webster A, DallAgnol B, et al. Multiple resistance to acaricides in field populations of Rhipicephalus microplus from Rio Grande do Sul state, Southern Brazil. Ticks and Tick-Borne Diseases. 2017;8(1):73-80.

7. Castro Janer E, Klafke GM, Capurro ML, et al. Cross-resistance between fipronil and lindane in Rhipicephalus (Boophilus) microplus. Veterinary Parasitology. 2015;210(1-2):77-83.

8. Adenubi OT, Fasina FO, McGaw L, et al. Plant extracts to control ticks of veterinary and medical importance: A review. South African Journal of Botany. 2016;105:178-193.

9. Singh NK, Jyoti VB, Prerna M, et al. Acaricidal activity of leaf extracts of DalbergiasissooRoxb. (Fabaceae) against synthetic pyrethroid resistant Rhipicephalus (Boophilus) microplus. Research in Veterinary Science. 2016;106:1-6.

10. Dantas ACS, Araujo AC, Pacheco AGM, et al. Acaricidal activity of Amburanacearensis on the cattle tick Rhipicephalus (Boophilus) microplus. Ciência Rural. 2015;46(3):536-541.

11. Wellington KW, Leboho T, Sakong BM, et al. Further studies on South African plants: Acaricidal activity of organic plant extracts against Rhipicephalus (Boophilus) microplus (Acari: Ixodidae). Veterinary Parasitology. 2017;234:10-12.

12. Adenubi OT, Ahmed AS, Fasina FO, et al. Pesticidal plants as a possible alternative to synthetic acaricides in tick control: A systematic review and meta-analysis. Industrial Crops and Products. 2018;123:779-806.
13. Medeiros-Neves B, Teixeira HF, von Poser GL. The genus Pterocaulon (Asteraceae) - A review on traditional medicinal uses, chemical constituents and biological properties. Journal of Ethnopharmacology. 2018;224:451-464.

14. Penta S. Advances in structure and activity relationship of coumarin derivatives. Amsterdam: Elsevier/Academic Press; 2015.

15. Hussain MI, Syed QA, Khattak MNK, et al. Natural product coumarins: biological and pharmacological perspectives. Biologia. 2019;74(7):863888.

16. Costa TM, Tavares LBB, \& de Oliveira D. Fungi as a source of natural coumarins production. Applied Microbiology and Biotechnology. 2016;100(15):6571-6584

17. Owino JO, Matasyoh JC, Guliye AY. AcaricidalCoumarins from the Medicinal Plant Acokantheraschimperi. Journal of Organic \& Inorganic Chemistry. 2015;1(1).

18. Pulido-Herrera LA, Rudas-L, A., Betancourt, J. A., et al. Distribución Inusual y Potencial de la Garrapata Común del Ganado, Rhipicephalus (Boophilus) microplus, en Zonas Tropicales de Alta Montaña de los Andes colombianos. Biota Colombiana (Instituto de Investigación de Recursos Biológicos “Alexander von Humboldt” Colombia). 2015;16(2):75-95.

19. Sungirai M, Moyo DZ, De Clercq P, et al. Modelling the distribution of Rhipicephalus microplus and R. decoloratus in Zimbabwe. Veterinary Parasitology: Regional Studies and Reports. 2018;14:41-49.

20. Korotkov Y, Kozlova T, Kozlovskaya L. Observations on changes in abundance of questing Ixodesricinus, castor bean tick, over a 35-year period in the eastern part of its range (Russia, Tula region). Medical and Veterinary Entomology. 2015;29(2):129-136.

21. Levin SA. Encyclopedia of biodiversity Volume 7 ST-ZO. 2nd ed. Amsterdam Boston Heidelberg Elsevier, Academic Press; 2013.

22. Almazan C. Immunological control of ticks and tick-borne diseases that impact cattle health and production. Frontiers in Bioscience. 2018;23(8):1535-1551.

23. Meng CQ, Sluder AE. Ectoparasites: Drug Discovery against Moving Targets. 1st ed. Weinheim: Wiley-Vch; 2018. 25-43p; 95-108 p.

24. Senbill H, Hazarika LK, Baruah A, et al. Life cycle of the southern cattle tick, Rhipicephalus (Boophilus) microplus Canestrini 1888 (Acari: Ixodidae) under laboratory conditions. Systematic and Applied Acarology. 2018;23(6):1169

25. Rodríguez Y, Rojas M, Gershwin ME, et al. Tick-borne diseases and autoimmunity: A comprehensive review. Journal of Autoimmunity. 2018;88:21-42.

26. Lyme Disease Data Tables: Historical Data. NCEZID; 2019

27. Manjunathachar HV, Saravanan BC, Kesavan M, et al. Economic importance of ticks and their effective control strategies. Asian Pacific Journal of Tropical Disease. 2014;4(Suppl 2):S770-S779.

28. Qin XC, Shi M, Tian JH, et al. A tick-borne segmented RNA virus contains genome segments derived from unsegmented viral ancestors. Proceedings of the National Academy of Sciences. 2014;111(18):67446749 .

29. Brackney DE, Armstrong PM. Transmission and evolution of tick-borne viruses. Current Opinion in Virology. 2016;21:67-74.

30. Souza WM de, Fumagalli MJ, Torres Carrasco A, et al. Viral diversity of Rhipicephalus microplus parasitizing cattle in southern Brazil. Scientific Reports. 2018;8(1).

31. Mtshali K, Khumalo Z, Nakao R, et al. Molecular detection of zoonotic tick-borne pathogens from ticks collected from ruminants in four South African provinces. Journal of Veterinary Medical Science. 2015;77(12):1573-1579. 
32. Rodino KG. Rickettsioses in the United States. Clinical Microbiology Newsletter. 2019;41(13):113-119.

33. Okafor CC, Collins SL, Daniel JA, et al. Factors associated with seroprevalence of bovine anaplasmosis in Mississippi, USA. Veterinary Parasitology: Regional Studies and Reports. 2019;17:100301.

34. Guo H, Adjou Moumouni PF, Thekisoe O, et al. Genetic characterization of tick-borne pathogens in ticks infesting cattle and sheep from three South African provinces. Ticks and Tick-Borne Diseases. 2019;10(4):875-882.

35. McCoy BN, Maïga O, Schwan TG. Detection of Borreliatheileri in Rhipicephalus geigyi from Mali. Ticks and Tick-Borne Diseases. 2014;5(4):401-403.

36. Kean IR, Irvine KL. Lyme disease: aetiopathogenesis, factors for disease development and control. Inflammopharmacology. 2012;21(2):101-111.

37. Brown SJ, Askenase PW. Analysis of Host Components Mediating Immune Resistance to Ticks. In Acarology VI. 1984; pp. 1040-1049.

38. Betancur Hurtado OJ, Giraldo-Ríos C. Economic and Health Impact of the Ticks in Production Animals. In M. Abubakar\& P. KanchanaPerera (Eds.), Ticks and Tick-Borne Pathogens; 2019.

39. Lew-Tabor AE, Rodriguez Valle M. A review of reverse vaccinology approaches for the development of vaccines against ticks and tick borne diseases. Ticks and Tick-Borne Diseases. 2016;7(4):573-585.

40. Grisi L, Leite RC, Martins JR, et al. Reassessment of the potential economic impact of cattle parasites in Brazil. Revista Brasileira de Parasitologia Veterinária. 2014;23(2):150-156.

41. Graham $\mathrm{OH}$, Hourrigan JL. Eradication programs for the arthropod parasites of livestock. Journal of Medical Entomology. 1977;13(6):629658

42. Rodríguez-Vivas RI, Grisi L, Pérez de León AA, et al. Potential economic impact assessment for cattle parasites in Mexico. Review. Revista Mexicana de Ciencias Pecuarias. 2017;8(1):61-74.

43. Puerta JM, Chaparro JJ, Lopez-Arias A, et al. Loss of in vitro Efficacy of Topical Commercial Acaricides on Rhipicephalus microplus (Ixodida: Ixodidae) From Antioquian Farms, Colombia. Journal of Medical Entomology. 2015;52(6):1309-1314.

44. Bissinger BW, Roe RM. Tick repellents: Past, present, and future Pesticide Biochemistry and Physiology. 2010;96(2):63-79.

45. de Oliveira PR, Calligaris IB, Roma GC, et al. Potential of the insect growth regulator, fluazuron, in the control of Rhipicephalus sanguineus nymphs (Latreille, 1806) (Acari: Ixodidae): Determination of the LD95 and LD50. Experimental Parasitology. 2012;131(1):35-39.

46. McTier TL, Chubb N, Curtis MP, et al. Discovery of sarolaner: A novel, orally administered, broad-spectrum, isoxazolineectoparasiticide for dogs. Veterinary Parasitology. 2016;222:3-11.

47. Modes of Action (MoA) Classification. IRAC; 2019.

48. Brito LG, de Oliveira Nery L, da Silva Barbieri F, et al. Molecular quantitative assay for esterase-mediated organophosphate resistance in Rhipicephalus microplus. Ticks and Tick-Borne Diseases. 2017;8(5):725732 .

49. Castro Janer E, Klafke GM, Fontes F, et al. Mutations in Rhipicephalus microplus GABA gated chloride channel gene associated with fipronil resistance. Ticks and Tick-Borne Diseases. 2019;10(4):761-765.

50. Aboelhadid SM, Arafa WM, Mahrous LN, et al. Molecular detection of Rhipicephalus (Boophilus) annulatus resistance against deltamethrin in middle Egypt. Veterinary Parasitology: Regional Studies and Reports. 2018;13:198-204.
51. Khangembam R, Singh H, Jyoti Rath SS, et al. Effect of synergists on ivermectin resistance in field populations of Rhipicephalus (Boophilus) microplus from Punjab districts, India. Ticks and Tick-Borne Diseases. 2018;9(3):682-686.

52. Rodriguez-Vivas RI, Jonsson NN, Bhushan C. Strategies for the control of Rhipicephalus microplus ticks in a world of conventional acaricide and macrocyclic lactone resistance. Parasitology Research. 2017;117(1):329

53. Mackerras IM. Recent developments in the control of cattle tick and buffalo-fly. Australian Veterinary Journal. 1947;23(7):185-189.

54. Adehan S, Adinci J, Yessinou RE, et al. In vitro acaricidal effect of Syzygiumaromaticum and Cymbopogoncitratus essential oil on engorged female of cattle tick Rhipicephalus microplus in Benin. Scientific Journal of Veterinary Advances. 2016;5(3):80-86.

55. Ntondini Z, Van Dalen EMSP, Ivan Gerard Horak. The extent of acaricide resistance in 1-, 2-and 3-host ticks on communally grazed cattle in the eastern region of the Eastern Cape Province, South Africa. Journal of the South African Veterinary Association. 2018;79(3):130-135.

56. Baron S, Barrero RA, Black M, et al. Differentially expressed genes in response to amitraz treatment suggests a proposed model of resistance to amitraz in R. decoloratus ticks. International Journal for Parasitology: Drugs and Drug Resistance. 2018;8(3):361-371.

57. Lovis L, Reggi J, Berggoetz M, et al. Determination of acaricide resistance in Rhipicephalus (Boophilus) microplus (Acari: Ixodidae) field populations of Argentina, South Africa, and Australia with the larval tarsal test. Journal of Medical Entomology. 2013;50(2):326-335.

58. KagarukiLK. Tick(Acari: Ixodidae)resistance to organochlorineacaricides in Tanzania. International Journal of Pest Management. 1991;37(1):3336.

59. Muyobela J, Nkunika POY, Mwase ET. Resistance status of ticks (Acari; Ixodidae) to amitraz and cypermethrinacaricides in Isoka District, Zambia. Tropical Animal Health and Production. 2015;47(8):1599-1605.

60. Cutullé C, Lovis L, D’Agostino BI, et al. In vitro diagnosis of the first case of amitraz resistance in Rhipicephalus microplus in Santo Tomé (Corrientes), Argentina. Veterinary Parasitology. 2013;192(1-3):296300 .

61. Lovis L, Mendes MC, Perret JL, et al. Use of the Larval Tarsal Test to determine acaricide resistance in Rhipicephalus (Boophilus) microplus Brazilian field populations. Veterinary Parasitology. 2013;191(3-4):323331.

62. Villarroel-Alvarez M, Rodríguez-Vivas RI, Villegas-Anze F, et al. Prevalence and potential risk factors for pyrethroids resistance in Boophilus microplus ticks on milk farms in Santa Cruz Department, Bolivia. TécnicaPecuaria en México. 2006;44(2):155-167.

63. Martins JR, Furlong J. Avermectin resistance of the cattle tick Boophilus microplus in Brazil. The Veterinary Record. 2001;149(2):64.

64. Li AY, Davey RB, Miller RJ, et al. Detection and characterization of amitraz resistance in the southern cattle tick, Boophilus microplus (Acari: Ixodidae). Journal of Medical Entomology. 2004;41(2):193-200.

65. Mendes MC, Pereira JR, Prado AP. Sensitivity of Boophilus microplus (Acari: Ixodidae) to pyrethroids and organophosphate in farms in the Vale do Paraíba region, São Paulo, Brazil. Arq Inst Biol. 2007;74(2):81-85.

66. Andreotti R, Garcia MV, Cunha RC, et al. Protective action of Tagetesminuta (Asteraceae) essential oil in the control of Rhipicephalus microplus (Canestrini, 1887) (Acari: Ixodidae) in a cattle pen trial. Veterinary Parasitology. 2013;197(1-2):341-345. 
67. Mendes MC, Lima CKP, Nogueira AHC, et al. Resistance to cypermethrin, deltamethrin and chlorpyriphos in populations of Rhipicephalus (Boophilus) microplus (Acari: Ixodidae) from small farms of the State of São Paulo, Brazil. Veterinary Parasitology. 2011;178(3-4):383-388.

68. Reck J, Klafke GM, Webster A, et al. First report of fluazuron resistance in Rhipicephalus microplus: a field tick population resistant to six classes of acaricides. Veterinary Parasitology. 2014;201(1-2):128-136.

69. Benavides E, Rodríguez JL, Romero A. Isolation and partial characterization of the Montecitosstrain of Boophilus microplus (Canestrini, 1877) multiresistant to different acaricides. Annals of the New York Academy of Sciences. 2000;916(1):668-671.

70. Díaz RE, Vallejo G. Identificación de un polimorfismo del gen Est9 relacionado con resistencia a piretroides en Rhipicephalus (Boophilus) microplus. Rev MVZ Córdoba. 2013;18(1):3708-3714.

71. Lopez-Arias A, Villar-Argaiz D, Chaparro-Gutierrez JJ, et al. Reduced efficacy of commercial acaricides against populations of resistant cattle tick Rhipicephalus microplus from two municipalities of Antioquia, Colombia. Environ Health Insights. 2014;8(2):71-80.

72. Araque A, Ujueta S, Bonilla R, et al. Resistencia a acaricidas en Rhipicephalus (Boophilus) microplus de algunas explotaciones ganaderas de Colombia. Revista UDCA Actualidad \& Divulgación Científica. 2014;17(1):161-170.

73. Villar D, Puerta J, López A, et al. Ivermectin resistance of three Rhipicephalus microplus populations using the larval immersion test. Revista Colombiana de Ciencias Pecuarias. 2016;29(1):51-57.

74. Villar D, Gutiérrez J, Piedrahita D, et al. Resistencia in vitro a acaricidas tópicos de poblaciones de garrapatas Rhipicephalus (Boophilus) microplus provenientes de cuatro departamentos de Colombia. Revista CES Medicina Veterinaria y Zootecnia. 2016;11(3):58-70.

75. Hagen S, Kopp Gómez JA, Liebisch A. Estudios de resistencia a acaricidas en la garrapata bovina Boophilus microplus en América Central. Seminario Internacional de Parasitología Animal; 1999. 20-22 p.

76. Álvarez V, Hernández V. Diagnostic for resistance to organophosphates, synthetic pyrethroids, amidines and ivermectines, in Rhipicephalus microplus ticks on dairy farms in Costa Rica. FAVE: revista de la Facultad de Ciencias Veterinarias-Sección Ciencias Veterinarias. 2010;9(2):7-8.

77. Valdez RM, Méndez ML, Guerra AA, et al. IV Seminario Internacional de Parasitología Animal. Control de la resistencia en garrapatas y moscas de importancia veterinaria y enfermedades que transmiten, CONASAGINIFAP-INFARVET-IICA-AMPAVEFILASA; 1999. 57-63 p.

78. Rawlins SC, Mansingh A. Patterns of resistance to various acaricides in some Jamaican populations of Boophilus microplus. Journal of Economic Entomology. 1978;71(6):956-960.

79. Ortiz Estrada M, Santamaria Vargas M, Ortiz Najera A, et al. Characterization of Boophilus microplus resistance to ixodicides in México. Seminario internacional de Parasitología Animal Acapulco, Gro: México; 1995. 58-66 p.

80. Fragoso H, Soberanes N, Ortiz M, et al. Epidemiología de la resistencia a ixodicidas piretroides en garrapatas Boophilus microplus en la República Mexicana. Seminario Internacional de Parasitología Animal-Resistencia y Control en Garrapatas y Moscas de Importancia Veterinaria; 1995. $45-57 \mathrm{p}$.

81. Soberanes CN, Santamaría VM, Fragoso $\mathrm{SH}$, et al. Primer caso de resistencia al amitraz en la garrapata del ganado Boophilus microplus en México. Téc Pec. 2002;40:81-90.

82. Rodríguez-Vivas RI, Rodriguez-Arevalo F, Alonso-Díaz MA, et al. Prevalence and potential risk factors for amitraz resistance in Boophilus microplus ticks in cattle farms in the State of Yucatan, Mexico. Preventive Veterinary Medicine. 2006;75(3-4):280-286.
83. Rodriguez-Vivas RI, Rivas AL, Chowell G, et al. Spatial distribution of acaricide profiles (Boophilus microplus strains susceptible or resistant to acaricides) in southeastern Mexico. Veterinary Parasitology. 2007;146(12):158-169.

84. Rosado-Aguilar JA, Rodriguez-Vivas RI, Garcia-Vazquez Z, et al. Development of amitraz resistance in field populations of Boophilus microplus (Acari: Ixodidae) undergoing typical amitraz exposure in the Mexican tropics. Veterinary Parasitology. 2008;152(3-4):349-353.

85. Fernández-Salas A, Rodríguez-Vivas RI, Alonso-Díaz MÁ. Resistance of Rhipicephalus microplus to amitraz and cypermethrin in tropical cattle farms in Veracruz, Mexico. Journal of Parasitology. 2012;98(5):1010 1014

86. Fernández-Salas A, Rodríguez-Vivas RI, Alonso-Díaz MA. First report of a Rhipicephalus microplus tick population multi-resistant to acaricides and ivermectin in the Mexican tropics. Veterinary Parasitology. 2012;183(3-4):338-342.

87. Perez-Cogollo LC, Rodriguez-Vivas RI, Ramirez-Cruz GT, et al. First report of the cattle tick Rhipicephalus microplus resistant to ivermectin in Mexico. Veterinary Parasitology. 2010;168(1-2):165-169.

88. Rodriguez-Vivas RI, Trees AJ, Rosado-Aguilar JA, et al. Evolution of acaricide resistance: phenotypic and genotypic changes in field populations of Rhipicephalus (Boophilus) microplus in response to pyrethroid selection pressure. International Journal for Parasitology. 2011;41(8):895-903.

89. Olivares-Pérez J, Rojas-Hernández S, Valencia-Almazan MT, et al Prevalence of resistant strains of Rhipicephalus microplus to acaricides in cattle ranch in the tropical region of Tecpan of Galeana, Guerrero, México. Pak Vet J. 2011;31(4):366-368.

90. Miller RJ, Almazán C, Ortíz-Estrada M, Davey RB, et al. First report of fipronil resistance in Rhipicephalus (Boophilus) microplus of Mexico. Veterinary Parasitology. 2013;191(1-2):97-101.

91. Rodriguez-Vivas RI, Li AY, Ojeda-Chi MM, et al. In vitro and in vivo evaluation of cypermethrin, amitraz, and piperonylbutoxide mixtures for the control of resistant Rhipicephalus (Boophilus) microplus (Acari: Ixodidae) in the Mexican tropics. Veterinary Parasitology. 2013;197(12):288-296.

92. Torrijos MJ, Avarez-Calderón V, Quintero-Noriega R, et al. Sensibilidad al clorpirifos y cipermetrina en la garrapata Rhipicephalus microplus en fincas ganaderas de panamá. Cien Agropec. 2015;2:70-77

93. Castro Janer E, Rifran L, González P, et al. Rhipicephalus (Boophilus) microplus (Acari: Ixodidae) resistance to fipronil in Uruguay evaluated by in vitro bioassays. Vet Parasitol. 2009;169(1-2):172-177

94. Castro Janer E, Rifran L, Gonzalez P, et al. Determination of the susceptibility of Rhipicephalus (Boophilus) microplus (Acari: Ixodidae) to ivermectin and fipronil by Larval Immersion Test (LIT) in Uruguay. Veterinary Parasitology. 2011;178(1-2):148-155.

95. Cuore U, Solari MA. Poblaciones multirresistentes de garrapatas Rhipicephalus (Boophilus) microplus en Uruguay. Veterinaria (Montevideo). 2014;50(193):4-13.

96. Castro Janer E, Klafke GM, Capurro ML, et al. Cross-resistance between fipronil and lindane in Rhipicephalus (Boophilus) microplus. Veterinary Parasitology. 2015;210(1-2):77-83.

97. Miller RJ, Davey RB, White WH, et al. A comparison of three bioassay techniques to determine amitraz susceptibility in Boophilus microplus (Acari: Ixodidae). Journal of Medical Entomology. 2007;44(2):283-294.

98. Busch JD, Stone NE, Nottingham R, et al. Widespread movement of invasive cattle fever ticks (Rhipicephalus microplus) in southern Texas leads to shared local infestations on cattle and deer. Parasites \& Vectors. 2014;7(1):188. 
99. Coronado A. Control químico de Boophilus microplus en Venezuela: Situación actual. Seminario Internacional de Parasitología Animal Puerto Vallarta, Jalisco (México); 1999.

100. Chaudhuri RP, Naithani RC. Resistance to BHC in the cattle tick Boophillus microplus (Can.) in India. Bulletin of Entomological Research. 1964;55(3):405-410.

101. Kumar S, Paul S, Sharma AK, et al. Diazinon resistant status in Rhipicephalus (Boophilus) microplus collected from different agroclimatic regions of India. Veterinary Parasitology. 2011;181(2-4):274281.

102. Sharma AK, Kumar R, Kumar S, et al. Deltamethrin and cypermethrin resistance status of Rhipicephalus (Boophilus) microplus collected from six agro-climatic regions of India. Veterinary Parasitology. 2012;188(34):337-345.

103. Shyma KP, Gupta JP, Ghosh S, et al. Acaricidal effect of herbal extracts against cattle tick Rhipicephalus (Boophilus) microplus using in vitro studies. Parasitology Research. 2014;113(5):1919-1926.

104. Singh NK, Haque M, Singh H, et al. A comparative study on cypermethrin resistance in Rhipicephalus (Boophilus) microplus and Hyalommaanatolicum from Punjab (India). Ticks and Tick-borne Diseases. 2014;5(2):90-94.

105. Singh NK, Singh H, Rath SS. Malathion resistance in Rhipicephalus (Boophilus) microplus from Ludhiana district, Punjab. Journal of Parasitic Diseases. 2014;38(4):343-346.

106. Singh NK, Gelot IS, Singh V, et al. Detection of amitraz resistance in Rhipicephalus (Boophilus) microplus from North Gujarat, India. Journal of Parasitic Diseases. 2015;39(1):49-52.

107. Ghosh S, Kumar R, Nagar G, et al. Survey of acaricides resistance status of Rhipiciphalus (Boophilus) microplus collected from selected places of Bihar, an eastern state of India. Ticks and tick-borne diseases. 2005;6(5):668-675.

108. Shyma KP, Gupta JP, Singh V, et al. In vitro detection of acaricidal resistance status of Rhipicephalus (Boophilus) microplus against commercial preparation of deltamethrin, flumethrin, and fipronil from North Gujarat, India. Journal of Parasitology Research. 2015;2015:506586.

109. Gaur RS, Sangwan AK, Sangwan N, et al. Acaricide resistance in Rhipicephalus (Boophilus) microplus and Hyalommaanatolicum collected from Haryana and Rajasthan states of India. Experimental and Applied Acarology. 2016;69(4):487-500.

110. Stone BF, Webber LG. Cattle ticks, Boophilus microplus, resistant to DDT, BHC, and dieldrin. Australian Journal of Agricultural Research. 1960;11(1):106-119.

111. Shaw RD. Culture of an organophosphorus-resistant strain of Boophilus microplus (Can.) and an assessment of its resistance spectrum. Bulletin of Entomological Research. 1966;56(3):389-405.

112. Nolan J, Wilson JT, Green PE, et al. Synthetic pyrethroid resistance in field samples in the cattle tick (Boophilus microplus). Australian Veterinary Journal. 1989;66(6):179-182.

113. Roulston WJ, Wharton RH, Nolan J, et al. A survey for resistance in cattle ticks to acaricides. Australian Veterinary Journal. 1981;57(8):362-371.

114. Jonsson NN, Hope M. Progress in the epidemiology and diagnosis of amitraz resistance in the cattle tick Boophilus microplus. Veterinary parasitology. 2007;146(3-4):193-198.

115. Brun LO, Wilson JT, Daynes P. Ethion resistance in the cattle tick (Boophilus microplus) in New Caledonia. International Journal of Pest Management. 1983;29(1):16-22.

116. Beugnet F, Chardonnet L Chardonnet. Tick resistance to pyrethroids in New Caledonia. Veterinary parasitology. 1995;56(4):325-338.
117. Bianchi MW, Barré N, Messad S. Factors related to cattle infestation level and resistance to acaricides in Boophilus microplus tick populations in New Caledonia. Veterinary Parasitology. 2003;112(1-2):75-89.

118. Ducornez S, Barré N, Miller RJ, et al. Diagnosis of amitraz resistance in Boophilus microplus in New Caledonia with the modified Larval Packet Test. Veterinary Parasitology. 2005;130(3-4):285-292.

119. Petermann J, Cauquil L, Hurlin JC, et al. Survey of cattle tick, Riphicephalus (Boophilus) microplus, resistance to amitraz and deltamethrin in New Caledonia. Veterinary Parasitology. 2016;217:64-70.

120. Souza Higa L de O, Garcia MV, Barros J, et al. Acaricide Resistance Status of the Rhipicephalus microplus in Brazil: A Literature Overview. Medicinal Chemistry. 2015;5(7):326-333.

121. Food and Agriculture Organization (FAO). Código Internacional de Conducta para la Distribución y Utilización de Plaguicidas Directrices sobre la Prevención y Manejo de la Resistencia a los Plaguicidas septiembre 2012. In FAO, Organización de las Naciones Unidas para la Alimentación y la Agricultura; 2013. 7-30 p.

122. Guerrero FD, Lovis L, Martins JR. Acaricide resistance mechanisms in Rhipicephalus (Boophilus) microplus. Revista Brasileira de Parasitologia Veterinária. 2012;21(1):1-6.

23. Vudriko P, Okwee-Acai J, Byaruhanga J, et al. Chemical tick control practices in southwestern and northwestern Uganda. Ticks and TickBorne Diseases. 2018;9(4):945-955.

124. Food and Agriculture Organization (FAO). Module 1. Ticks: Acaricide resistance: Diagnosis, Management and Prevention. In FAO (Food and Agriculture Organization) (Ed.), Guidelines Resistance Management and Integrated Parasite Control in Ruminants; 2004 25-77 p.

25. Chigure GM, Sharma AK, Kumar S, et al. Role of metabolic enzymes in conferring resistance to synthetic pyrethroids, organophosphates, and phenylpyrazole compounds in Rhipicephalus microplus. International Journal of Acarology. 2017;44(1):28-34.

126. Janadaree Bandara KMU, Parakrama Karunaratne SHP. Mechanisms of acaricide resistance in the cattle tick Rhipicephalus (Boophilus) microplus in Sri Lanka. Pesticide Biochemistry and Physiology. 2017;139(139):6872.

127. Soares SF, Borges LMF. Electrophysiological responses of the olfactory receptors of the tick Amblyommacajennense (Acari: Ixodidae) to hostrelated and tick pheromone-related synthetic compounds. Acta Tropica. 2012;124(3):192-198.

28. Kluck GEG, Silva Cardoso L, De Cicco NNT, et al. A new lipid carrier protein in the cattle tick Rhipicephalus microplus. Ticks and Tick-Borne Diseases. 2018;9(4):850-859.

129. Klafke GM, Miller RJ, Tidwell JP, et al. High-resolution melt (HRM) analysis for detection of SNPs associated with pyrethroid resistance in the southern cattle fever tick, Rhipicephalus (Boophilus) microplus (Acari: Ixodidae). International Journal for Parasitology: Drugs and Drug Resistance. 2019:9:100-111.

130. Panini M, Manicardi GC, Mazzoni E, et al. An overview of the main pathways of metabolic resistance in insects. Invertebrate Survival Journal. 2016;13(1):326-335.

131. Pulido Suárez NJ, Cruz Carrillo A. Eficacia de los extractos hidroalcohólicos de dos plantas sobre garrapatas adultas Rhipicephalus (Boophilus) microplus. Corpoica Ciencia y Tecnología Agropecuaria. 2013;14(1):91.

132. Dantas ACS, Machado DMR, Araujo AC, et al. Acaricidal activity of extracts from the leaves and aerial parts of Neoglazioviavariegata (Bromeliaceae) on the cattle tick Rhipicephalus (Boophilus) microplus. Research in Veterinary Science. 2015;100:165-168. 
133. Singh NK, Miller RJ, Klafke GM, et al. In-vitro efficacy of a botanical acaricide and its active ingredients against larvae of susceptible and acaricide-resistant strains of Rhipicephalus (Boophilus) microplus Canestrini (Acari: Ixodidae). Ticks and Tick-Borne Diseases. 2018;9(2):201-206.

134. Rodríguez Molano CE, Pulido Suárez NJ. Eficacia de extractos vegetales sobre la garrapata adulta Rhipicephalus (Boophilus) microplus y su oviposición. Revista Cubana de Plantas Medicinales. 2015;20(4):375388 .

135. Pazinato R, Volpato A, Baldissera MD, et al. In vitro effect of seven essential oils on the reproduction of the cattle tick Rhipicephalus microplus. Journal of Advanced Research. 2016;7(6):1029-1034.

136. Kumar KGA, Tayade AB, Kumar R., et al. Chemo-profiling and bioassay of phytoextracts from Ageratum conyzoides for acaricidal properties against Rhipicephalus (Boophilus) microplus (Acari: Ixodidae) infesting cattle and buffaloes in India. Ticks and Tick-Borne Diseases. 2016;7(2):342-349.

137. Anholeto LA, Oliveira PR de, Rodrigues RAF, et al. Potential action of extract of Acmellaoleracea (L.) R.K. Jansen to control Amblyommacajennense (Fabricius, 1787) (Acari: Ixodidae) ticks. Ticks and Tick-Borne Diseases. 2017;8(1):65-72.

138. Figueiredo A, Nascimento LM, Lopes LG. et al. First report of the effect of Ocoteaelegans essential oil on Rhipicephalus (Boophilus) microplus. Veterinary Parasitology. 2018;252:131-136.

139. Pulido Suárez N, Moyano Bautista M, Rodríguez Molano C. Evaluación de varias especies vegetales para inhibir la oviposición y controlar la proliferación de Rhipicephalus (Boophilus) microplus. Revista Cubana De Plantas Medicinales. 2018;23(1).

140. Tan T, Luo Y, Zhong CC, et al. Comprehensive profiling and characterization of coumarins from roots, stems, leaves, branches, and seeds of ChimonanthusnitensOliv using ultra-performance liquid chromatography/quadrupole-time-of-flight mass spectrometry combined with modified mass defect filter. Journal of Pharmaceutical and Biomedical Analysis. 2017;141:140-148.

141. Al-Amiery AA, Al-Majedy YK, Kadhum AAH, et al. Nove macromolecules derived from coumarin: synthesis and antioxidant activity. Scientific Reports. 2015;5(1)

142. Stringlis IA, de Jonge R, Pieterse CMJ. The Age of Coumarins in PlantMicrobe Interactions. Plant and Cell Physiology. 2019;60(7):1405-1419.

143. Borges F, Roleira F, Milhazes N, et al. Simple Coumarins and Analogues in Medicinal Chemistry: Occurrence, Synthesis and Biological Activity. Current Medicinal Chemistry. 2005;12(8):887-916.

144. Seshadri TR, Murti VVS. Insecticidal properties and chemical constitution Part II cumarins. Proceedings of the Indian Academy of Sciences - Section A. $1947 ; 25(4): 333-336$

145. Link KP. The Discovery of Dicumarol and Its Sequels. Circulation. 1959;19(1):97-107.

146. Mueller RL. First-generation agents: aspirin, heparin and coumarins. Best Practice \& Research Clinical Haematology. 2004;17(1):23-53.

147. Clatanoff DV. Clinical experience with coumarin anticoagulants warfarin and warfarin sodium. Archives of Internal Medicine. 1954;94(2):213-220.

148. CFR - Code of Federal Regulations Title 21. FDA, U. S. F. A. D. A; 2018

149. Hazleton LW, Tusing TW, Zeitlin BR, et al. Toxicity of coumarin. Journal of Pharmacology and Experimental Therapeutics. 1956;118(3):348-358.

150. Krüger S, Winheim L, Morlock GE. Planar chromatographic screening and quantification of coumarin in food, confirmed by mass spectrometry. Food Chemistry. 2018;239:1182-1191.
151. Soine TO. Naturally Occurring Coumarins and Related Physiological Activities. Journal of Pharmaceutical Sciences. 1964;53(3): 231-264.

152. Kosuge T, Conn EE. The metabolism of aromatic compounds in higher plants. I. Coumarin and o-coumaric acid. The Journal of Biological Chemistry. 1959;234(8):2133-2137.

153. Brown SA. Biosynthesis of Coumarin and Herniarin in Lavender. Science. 1962;137(3534):977-978

154. Bourgaud F, Hehn A, Larbat R, et al. Biosynthesis of coumarins in plants: a major pathway still to be unravelled for cytochrome P450 enzymes. Phytochemistry Reviews. 2006;5(2-3):293-308.

155. Bradberry S, Vale A. Warfarin and anticoagulant rodenticides. Medicine. 2016;44(3):201.

156. Hadler MR, Buckle AP. Forty-five years of anticoagulant rodenticides-past, present and future trends. Proceedings of the Vertebrate Pest Conference; 2016.8 p.

157. Harvey RG, Cortez C, Ananthanarayan TP, et al. A new coumarin synthesis and its utilization for the synthesis of polycyclic coumarin compounds with anticarcinogenic properties. The Journal of Organic Chemistry. 1998;53(17):3936-3943.

158. Lake B, Evans J, Chapuis F, et al. Studies on the disposition, metabolism and hepatotoxicity of coumarin in the rat and Syrian hamster. Food and Chemical Toxicology. 2002;40(6):809-823.

159. Kostova I. Synthetic and Natural Coumarins as Cytotoxic Agents. Curren Medicinal Chemistry-Anti-Cancer Agents. 2005;5(1):29-46.

160. Marques de S, Salles DB, Maistro EL. Assessment of the genotoxic/ clastogenic potential of coumarin derivative 6,7-dihydroxycoumarin (aesculetin) in multiple mouse organs. Toxicology Reports. 2015;2:268274.

161. Al-Amiery AA, Al-Majedy YK, Kadhum AAH, et al. Novel macromolecules derived from coumarin: synthesis and antioxidant activity. Scientific Reports. 2015;5:11825.

162. Bedoya LM, Beltrán M, Sancho R., et al. 4-Phenylcoumarins as HIV transcription inhibitors. Bioorganic \& Medicinal Chemistry Letters. 2005;15(20):4447-4450.

163. Lin $\mathrm{MH}$, Wang JS, Hsieh $\mathrm{YC}$, et al. NO2 functionalized coumarin derivatives suppress cancer progression and facilitate apoptotic cell death in KRAS mutant colon cancer. Chemico-Biological Interactions. 2019;309:108708

164. Hwu JR, Huang WC, Lin SY, et al. Chikungunya virus inhibition by synthetic coumarin-guanosine conjugates. European Journal of Medicinal Chemistry. 2019;166:136-143.

165. Keri RS, Sasidhar BS, Nagaraja BM, et al. Recent Progress in the Drug Development of Coumarin Derivatives as Potent Antituberculosis Agents. Eur J Med Chem. 2015;100:257-269.

166. Vargas-Soto FA, Céspedes-Acuña CL, Aqueveque-Muñoz PM, et al Toxicity of coumarins synthesized by Pechmann-Duisbergcondensation against Drosophila melanogaster larvae and antibacterial effects. Food and Chemical Toxicology. 2017;109(Pt 2):1118-1124.

167. Sarker S, Nahar L. Progress in the Chemistry of Naturally Occurring Coumarins. In H. Falk, S. Gibbons, \& J. Kobayashi (Eds.), Progress in the Chemistry of Organic Natural Products. Springer International Publishing; 2017. 241-246 p.

168. Abernethy JL. The historical and current interest in coumarin. Journal of Chemical Education. 1969;46(9):561.

169. Bourgaud F, Poutaraud A, Guckert A. Extraction of coumarins from plant material (Leguminosae). Phytochemical Analysis. 1994;5(3):127-132. 
170. Stefanachi A, Leonetti F, Pisani L, et al. Coumarin: A Natural, Privileged and Versatile Scaffold for Bioactive Compounds. Molecules. 2018;23(2):250.

171. Lončarić M, Gašo-Sokač D, Jokić S, et al. Recent Advances in the Synthesis of Coumarin Derivatives from Different Starting Materials. Biomolecules. 2020;10(1):151.

172. Jerković I, Molnar M, Vidović S, et al. Supercritical CO2 Extraction of Lavandulaangustifolia Mill. Flowers: Optimisation of Oxygenated Monoterpenes, Coumarin and Herniarin Content. Phytochemical Analysis. 2017;28(6):558-566.

173. Deans BJ, Just J, Chhetri J, et al. Pressurized Hot Water Extraction as a Viable Bioprospecting Tool: Isolation of Coumarin Natural Products from Previously Unexamined Correa (Rutaceae) Species. Chemistry Select. 2017;2(8):2439-2443.

174. Kim JH. Extraction time and temperature affect the extraction efficiencies of coumarin and phenylpropanoids from Cinnamomum cassia bark using a microwave-assisted extraction method. Journal of Chromatography B. 2017;1063:196-203

175. $\mathrm{Hu}$ YH, Wang QY, Ye LH, et al. Effervescent salt and crown etherassisted matrix solid-phase dispersion extraction of coumarins from Cortex fraxini. Industrial Crops and Products. 2019;141:111752.

176. Cueva Quiroz MM. Utilización de la radiación de microonda para la síntesis de cuatro cumarinas, mediante Condensación de Knoevenagel; 2013. 11-21 p.

177. Cao D, Liu Z, Verwilst P, et al. Coumarin-Based Small-Molecule Fluorescent Chemosensors. Chemical Reviews. 2019;119(18): 1040310519 .

178. Bogdał D. Coumarins: Fast Synthesis by Knoevenagel Condensation unde Microwave Irradiation. Journal of Chemical Research. 1998;8:468-469.

179. Trost BM. Comprehensive organic synthesis. Pergamon; 1999. 277-299 p.

180. Delbrouck JA, Chêne LP, Vincent SP. Fluorosugars as inhibitors of bacterial enzymes. In G. Haufe\& F. R. Leroux (Eds.), Fluorine in Life Sciences: Pharmaceuticals, Medicinal Diagnostics, and Agrochemicals; 2019. 242-279 p.

181. Heravi MM, Ghanbarian M, Zadsirjan V, et al. Recent advances in the applications of Wittig reaction in the total synthesis of natural products containing lactone, pyrone, and lactam as a scaffold. Monatshefte Für Chemie-Chemical Monthly. 2019;150(8):1365-1407.

182. Ghomi JS, Akbarzadeh Z. Ultrasonic accelerated Knoevenage condensation by magnetically recoverable $\mathrm{MgFe} 2 \mathrm{O} 4$ nanocatalyst: A rapid and green synthesis of coumarins under solvent-free conditions. Ultrasonics Sonochemistry. 2018;40(Pt A):78-83.

183. de Souza LG, Rennó MN, Figueroa-Villar JD. Coumarins as cholinesterase inhibitors: A review. Chemico-Biological Interactions. 2016;254:11-23.

184. Pornsatitworakul S, Boekfa B, Maihom T, et al. The coumarin synthesis: a combined experimental and theoretical study. Monatshefte Für Chemie - Chemical Monthly. 2017;148(7):1245-1250.
185. Safaei-Ghomi J,Akbarzadeh Z, Teymuri R. ZnS nanoparticles immobilized on graphitic carbon nitride as a recyclable and environmentally friendly catalyst for synthesis of 3-cinnamoyl coumarins. Research on Chemical Intermediates. 2019;45(6):3425-3439.

186. Khan MS, Agrawal R, Ubaidullah M, et al. Design, synthesis and validation of anti-microbial coumarin derivatives: An efficient green approach. Heliyon. 2019;5(10):e02615.

187. Khaldi-Khellafi N, Oukacha-Hikem D, Bouaziz ST, et al. Green synthesis, characterization, structure, biological activity, theoretical calculations and drug-likeness analysis of coumarins. Chemical Data Collections. 2020;25:1-25.

188. Tanuraghaj HM, Farahi M. A novel sodium carbonate-catalyzed regioselective synthesis of pyrano[2,3-h]coumarins using a threecomponent reaction. Tetrahedron Letters. 2019;60(7):557-559.

189. Albadi J, Shirini F, Abasi J, et al. A green, efficient and recyclable poly(4-vinylpyridine)-supported copper iodide catalyst for the synthesis of coumarin derivatives under solvent-free conditions. Comptes Rendus Chimie. 2013;16(5):407-411.

190. He M, Yan Z, Wang W, et al. Copper-catalyzed radical/radical crosscoupling of ketoxime carboxylates with 4-hydroxycoumarins: A novel synthesis of furo[3,2-c]-coumarins. Tetrahedron Letters. 2018;59(41):3706-3712.

191. Mangasuli SN, Hosamani KM, Managutti PB. Synthesis of nove coumarin derivatives bearing dithiocarbamate moiety: An approach to microwave, molecular docking, Hirshfeld surface analysis, DFT studies and potent anti-microbial agents. Journal of Molecular Structure. 2019;1195:58-72.

192. Tunón H, Thorsell W, Mikiver A, et al. Arthropod repellency, especially tick (Ixodesricinus), exerted by extract from Artemisia abrotanum and essential oil from flowers of Dianthus caryophyllum. Fitoterapia. 2006;77(4):257-261.

193. Hess SC. Estudos quimicos, biologicos e farmacológicos com vochysia divergens pohl (vochysiaceae) e com ocotea suaveolens (meissn.) Hassler (Lauraceae) Tesis doctoral; 1995.

194. Gontijo DC, Brandão GC, Gontijo PC, et al. Identification of phenolic compounds and biologically related activities from Ocoteaodorifera aqueous extract leaves. Food Chemistry. 2017;230:618-626.

195. Rosado-Aguilar JA, Arjona-Cambranes K, Torres-Acosta JFJ, et al. Plant products and secondary metabolites with acaricide activity against ticks. Veterinary Parasitology. 2017;238:66-76

196. Fernández-Salas A, Alonso-Díaz MA, Acosta-Rodríguez R, et al. In vitro acaricidal effect of tannin-rich plants against the cattle tick Rhipicephalus (Boophilus) microplus (Acari: Ixodidae). Veterinary Parasitology. 2011;175(1-2):113-118.

197. Enan E. Insecticidal activity of essential oils: octopaminergic sites of action. Comparative Biochemistry and Physiology Part C: Toxicology \& Pharmacology. 2001;130(3):325-337.

198. Ntalli N, Koliopoulos G, Giatropoulos A, et al. Plant secondary metabolites against arthropods of medical importance. Phytochemistry Reviews. 2019;18(5):1255-1275. 